\title{
Late Pleistocene Panthera leo spelaea (Goldfuss, 1810) skeletons from the Czech Republic (central Europe); their pathological cranial features and injuries resulting from intraspecific fights, conflicts with hyenas, and attacks on cave bears
}

\author{
CAJUS G. DIEDRICH
}

\begin{abstract}
The world's first mounted "skeletons" of the Late Pleistocene Panthera leo spelaea (Goldfuss, 1810) from the Sloup Cave hyena and cave bear den in the Moravian Karst (Czech Republic, central Europe) are compilations that have used bones from several different individuals. These skeletons are described and compared with the most complete known skeleton in Europe from a single individual, a lioness skeleton from the hyena den site at the Srbsko Chlum-Komín Cave in the Bohemian Karst (Czech Republic). Pathological features such as rib fractures and brain-case damage in these specimens, and also in other skulls from the Zoolithen Cave (Germany) that were used for comparison, are indicative of intraspecific fights, fights with Ice Age spotted hyenas, and possibly also of fights with cave bears. In contrast, other skulls from the Perick and Zoolithen caves in Germany and the Urșilor Cave in Romania exhibit post mortem damage in the form of bites and fractures probably caused either by hyena scavenging or by lion cannibalism. In the Srbsko Chlum-Komín Cave a young and brain-damaged lioness appears to have died (or possibly been killed by hyenas) within the hyena prey-storage den. In the cave bear dominated bone-rich Sloup and Zoolithen caves of central Europe it appears that lions may have actively hunted cave bears, mainly during their hibernation. Bears may have occasionally injured or even killed predating lions, but in contrast to hyenas, the bears were herbivorous and so did not feed on the lion carcasses. The articulated lion skeletons found in cave bear dens deep within caves scattered across Europe (such as those from the Sloup, Zoolithen and Urșilor caves) can therefore now be explained as being the result of lions being killed during predation on cave bears, either by the cave bears defending themselves or as a result of interspecific fights. $\bullet$ Key words: Panthera leo spelaea (Goldfuss, 1810), steppe lion skeletons, Late Pleistocene, Czech Republic, taphonomy and pathology, palaeobiology.
\end{abstract}

DIEDRICH, C.G. 2011. Late Pleistocene Panthera leo spelaea (Goldfuss, 1810) skeletons from the Czech Republic (central Europe); their pathological cranial features and injuries resulting from intraspecific fights, conflicts with hyenas, and attacks on cave bears. Bulletin of Geosciences 86(4), 817-840 (13 figures, 2 tables). Czech Geological Survey, Prague. ISSN 1214-1119. Manuscript received March 15, 2011 ; accepted in revised form August 29, 2011; published online November 9, 2011; issued November 16, 2011.

Cajus G. Diedrich, PaleoLogic Research Institute, Nansenstrasse 8, D-33790, Halle/Westphalia, Germany; cdiedri@ gmx.net

The Late Pleistocene Eurasian steppe lion species, a close relative to an extinct subspecies of the modern African lion (from DNA - see Burger et al. 2004), was first described and illustrated from the Zoolithen Cave site in Bavaria, southern Germany, and classified as the "cave lion" Felis spelaea Goldfuss (1810). The large male holotype skull, with its pathological bite mark features, has recently been relocated and reclassified as the "steppe lion" (popular name by Diedrich 2008) Panthera leo spelaea (Goldfuss, 1810) (DNA by Burger et al. 2004). The steppe lion population from this cave is the largest known in Europe; it has recently been reviewed and discussed in a broad taphonomic and palaeobiological context relating to predation on cave bears and conflicts with hyenas (Diedrich 2010d, 2011a).

Following this discovery 200 years ago other important Pleistocene lion finds have become famous such as the oldest mounted "cave lion skeletons" described herein from the Sloup Cave (Fig. 1A, B) in the Moravian Karst (Czech Republic, central Europe), a hyena and cave bear den site (Diedrich 2009c, 2011b). The first of the two "skeletons" of Sloup Cave ( $c f$. Wankel 1858; "skeleton 2" - Brno, herein; Fig. 1B) is exhibited in the Anthropos Museum, Brno. Wankel (1888) later referred to a second skeleton 
("skeleton 1" - Vienna, herein; Fig. 1A) and also illustrated an additional skull from the same cave. The two mounted "skeletons" of the cave lion Felis spelaea were compiled from material found in the Cut-Stone Gallery of the Sloup Cave ( $c f$. Wankel 1858, 1868, 1888; Fig. 2). This material is critically analysed herein, together with new discoveries from the 1997 Sloup Cave excavations ( $c f$. Seitl 1998) that comprise another large male skull and some postcranial bones (Diedrich 2011). Wankel (1892) carried out further excavations at the Sloup Cave and reported two more "lion skeletons", one with a pathological condition on the lower jaw, and the other described as being also "quite complete", but whether these still exist and if so, where they are stored, remains unclear.

Lion remains have also been reported from the Moravian Karst in other publications, particularly from the Sloup and Výpustek caves but also from other caves, and are listed by Musil (1956). A preliminary overview of the Bohemian and Moravian Karst lion localities is presented herein (Fig. 2). The analysis of lion bone material from these sites is incomplete and warrants further investigations.

Lion remains have been reported from the Turská Maštal Cave (Kafka 1903) and the Chlupáčova sluj Cave on the Kobyla Hill near Koněprusy (Zázvorka 1954), in the Bohemian Karst in the Czech Republic consisting of just single bones and one single cub skeleton remain have been published, from which these sites have recently been interpreted to be both hyena prey depots and hyena dens (Diedrich \& Žák 2006). The material requires further study, however, as it includes a lion cub skeleton from the Chlupáčova sluj Cave. The most complete known lion skeleton in Europe from a single individual (from the Srbsko Chlum-Komín Cave in the Bohemian Karst) had been previously illustrated (Diedrich \& Žák 2006) but was relocated and studied in detail about 35 years later herein. This site yielded approximately 1,500 bone remains from horses, apparently accumulated by a hyena clan that had developed a specialization in hunting horses in response to the scarcity of mammoths in the mountainous regions (restricted to the Berounka River valley) of the Bohemian Karst (Diedrich 2010a).

Lion remains from Late Pleistocene open air sites have been reported from localities around Prague (Vltava River terrace; Diedrich 2007a) and Beroun (Berounka River terrace; Kafka 1903, Diedrich 2007a; Fig. 3) in the
Czech Republic. This material, which includes a skull, teeth, and isolated skeletal bones, has recently been re-described together with material from several other open air localities in the north-western Czech Republic, including Trmice (Diedrich 2007a).

Skeletons of the Late Pleistocene steppe lion Panthera leo spelaea have also been reported from a few other sites in Europe. The oldest known skeleton is from the cave bear den in the Azé Cave (France), and has been dated into the Saalian of the late Middle Pleistocene (Argant 1988). The skeleton of a senile lioness with pathological features, which was found in an elephant graveyard at the German Neumark-Nord-Lake 1 site, was from the Eemian interglacial of the early Late Pleistocene (Diedrich $2010 b, c)$. The number of recorded skeletons then increases during the cold period of the Weichsel/Würm glaciation (Late Pleistocene). A largely intact skeleton of a large, strong male lion was found in the Arrikrutz Cave in Spain (Altuna 1981), another was described from Salzburg in Austria (Tichy 1985), and a third male skeleton was found in an open air site at Siegsdorf in Germany (Gross 1992). The recent discoveries of lion skeletons deep within the Romanian Urșilor Cave (Diedrich et al. 2009) are the most spectacular because they represent the first clear evidence that steppe lions hunted cave bears deep within their caves (Diedrich 2011f). Skeletal remains from the Zoolithen Cave have also been reviewed recently but complete skeletons could not be compiled (Diedrich 2010d).

The main objective of this contribution is to critically re-examine the historical Sloup Cave lion skeleton compilations, together with the bones of the only known lioness skeleton from the Czech Republic (from the Srbsko Chlum-Komín Cave), which is illustrated in a bone catalogue (Figs 6-9) for osteological comparisons. A second objective, including this historical (largely unstudied) bone material, was to examine the bite damage and other pathological features on the lion material from the Czech Republic, with respect to interspecific and intraspecific antagonism and resulting skull damage. These important steppe lion cave finds are compared, mainly with respect to their taphonomy and pathological features, to steppe lion material from other caves (Diedrich 2009a, b, 20110d, 2011e) and open air sites, both in Germany and in the Czech Republic (Diedrich 2007a, 2010b, 2011d; Diedrich \& Rathgeber 2011).

Figure 1. Two first complete European (composite) skeletons of the Late Pleistocene steppe lion Panthera leo spelaea (Goldfuss, 1810), whose bones were mainly found in the Cut-Stone Gallery of the Sloup Cave, in the Moravian Karst of the Czech Republic (composite phalanges also from Výpustek Cave). $\bullet$ A - skeleton 1 ( $c f$. also Figs 2, 3), which was donated in 1885 by the Prince of Liechtenstein to the Natural History Museum in Vienna, Austria (NHMV No. 1885/0014/4302), in lateral view. • B - skeleton 2 ( $c f$. also Figs 2, 3) in the Anthropos Museum Brno, Czech Republic (AMB without No.), which has several flaws (the pes are transposed, the atlas is transposed, there are no sternal bones), in lateral and cranial views (historical drawings from Wankel 1888). 
Cajus G. Diedrich • Late Pleistocene Panthera leo spelaea skeletons from the Czech Republic
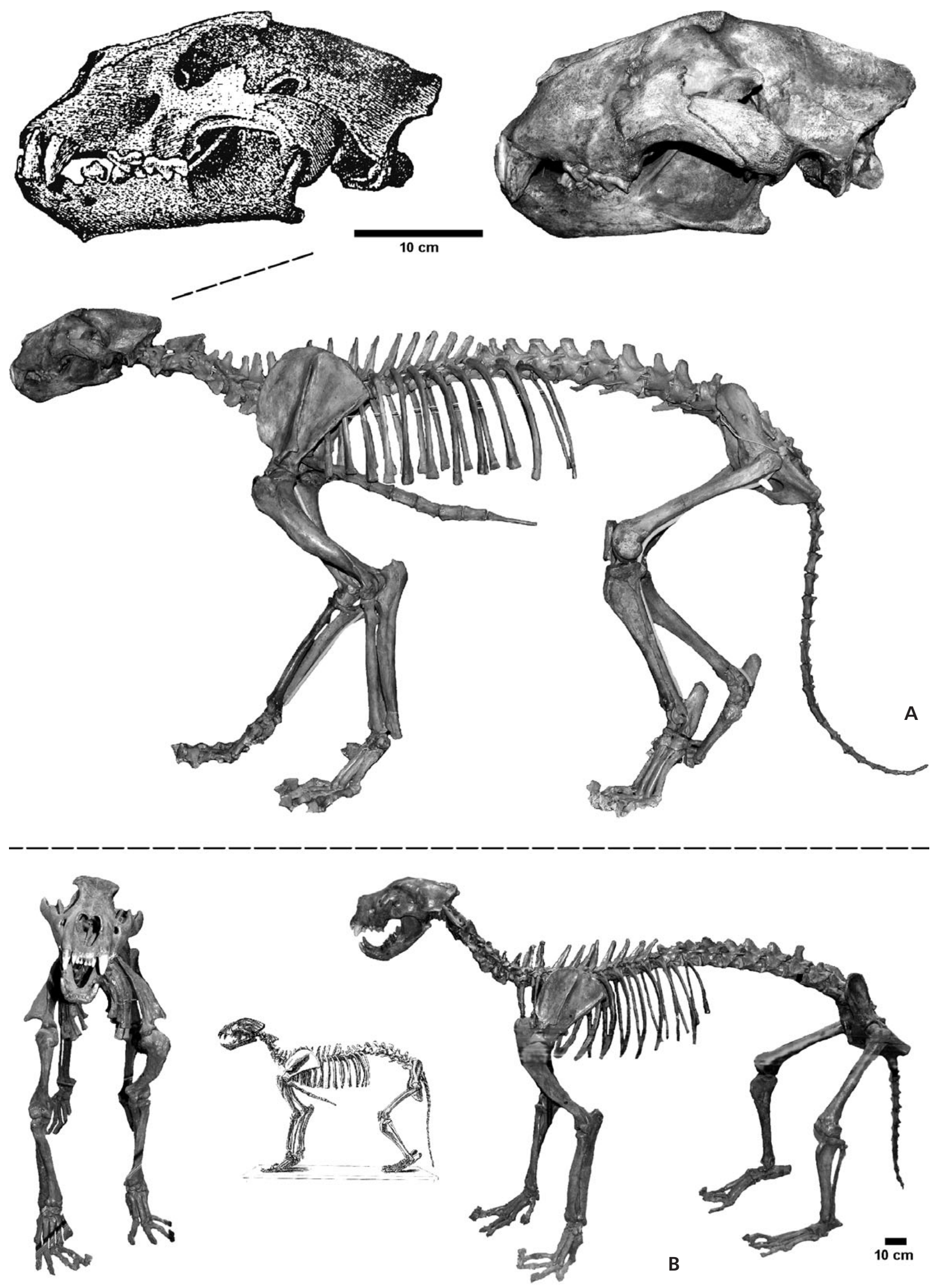


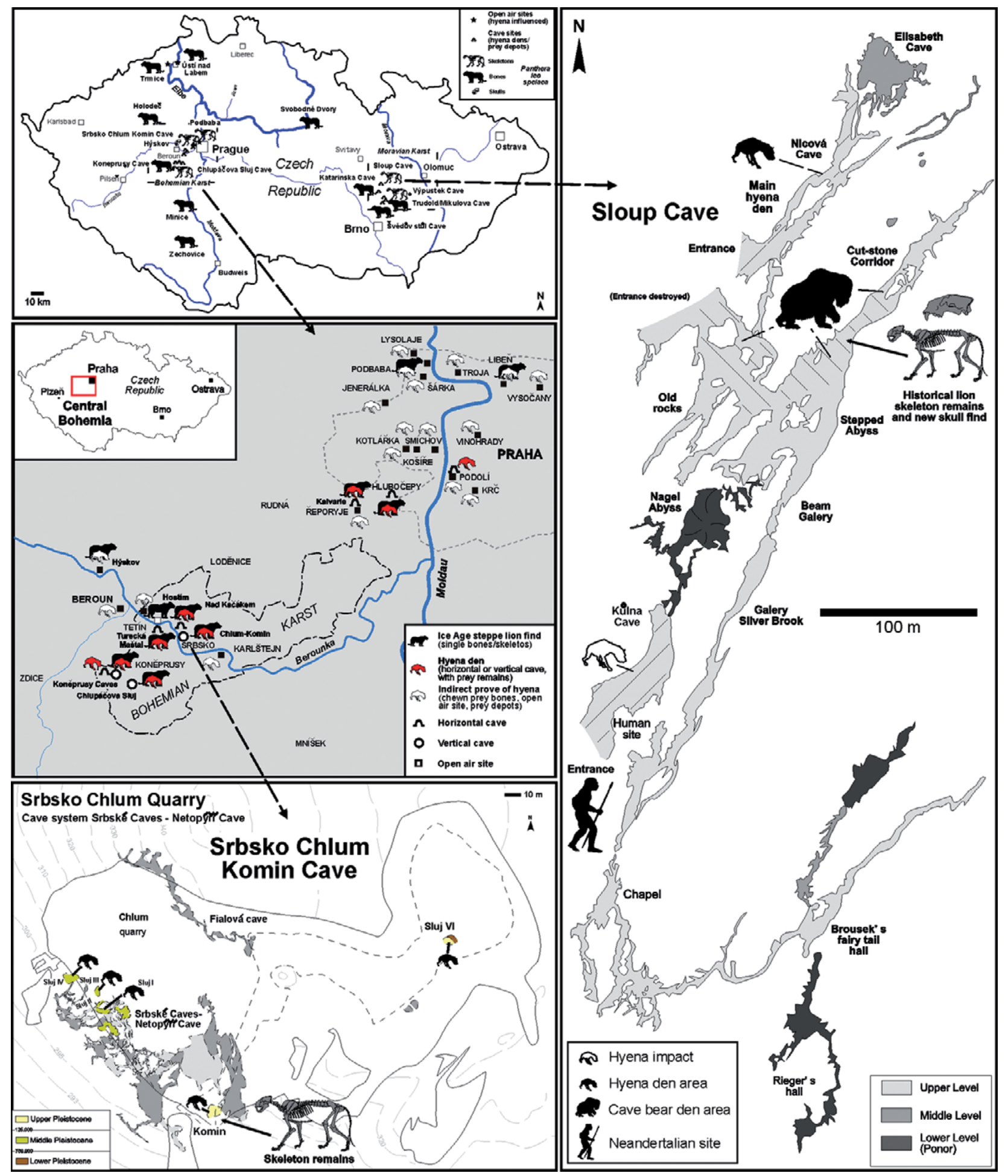

Figure 2. Late Pleistocene steppe lion open air and cave localities and hyena den sites in the Czech Republic, with details from Central Bohemia, Czech Republic (compiled from Diedrich \& Žák 2006; Diedrich 2007c, 2011, and the Sloup Cave map after Zajíček 2007).

\section{Material, history and methods}

This paper examines three lion "skeletons" from the Sloup (Moravian Karst) and Srbsko Chlum-Komín (Bohemian
Karst) caves, together with isolated material from various cave and open air sites in the Czech Republic. Dimensions and bite damage on skulls are compared to steppe lion, hyena (hyena prey), and cave bear material from other 
European sites such as the Perick and Zoolithen caves in German and the Urşilor Cave in Romanian. Historically collected steppe lion material from the Sloup Cave is housed in the Natural History Museum, Vienna (NHMV) comprising a single skeleton ("skeleton 1" - Vienna, herein) and some isolated bones. The Sloup Cave megafauna of the Wankel collections was received by the Natural History Museum of Vienna in 1885, forming one of its first palaeontological collections, but had been excavated in 1881-1882 for J. Wankel by V. Sedlák (an employee of the Czech Professor K. Absolon). This material seems to have been used mainly for the skeleton reconstruction donated to the museum in 1885 by the Prince of Liechtenstein. A third lion skull was from the excavations by Seitl in 1998, which was again found in the Cut-Stone Gallery where the other lion bones had been found historically. This material is stored in the Anthropos Museum, Brno (AMB), as is the second "skeleton" from the Sloup Cave ("skeleton 2" Brno, herein). The Sloup Cave ("Slouper-Höhle" in German) and the Výpustek Cave ("Kiritein Höhle" in German) were explored by the author prior to the $13^{\text {th }}$ International Cave Bear Symposium in 2007 to identify the areas excavated historically by Wankel and Sedlak, and the more recent excavations by Seitl.

The unsystematic pickaxe-and-shovel digs of the Speleoclub Praha in 1968-1969 caused extensive damage to a lion skeleton from the Srbsko Chlum-Komín Cave ("skeleton 3" herein), now housed in the Natural History Museum, Prague (NMP). The skeleton was finally completed in 2005 with the inclusion of many bone fragments found 36 years after the "cave cleaning", including one rib fragment, three scapula fragments from both right and left scapulas, and one upper jaw $\mathrm{M}^{1}$ tooth. It is now one of very few almost complete European Late Pleistocene steppe lion skeletons from a single individual and includes 149 bones (Table 1). This skeletal material was separated from that from a second, smaller skeleton of a one year old cub, which is represented by only $1 / 3$ of its bones and exhibits typically non-fused joints. The Srbsko Chlum-Komín Cave has yielded more then 3,500 bones, including about 350 hyena remains, as well as their coprolites, and a large quantity of hyena prey (dominated by horse remains - including a foetal skeleton). Cave bear bones have not been recorded in this Srbsko Chlum-Komín hyena den cave.

The dimensions of lion skulls from recently discovered cave and open air sites in the Czech Republic, as well as those from other skeletal and skull remains in Europe (including the long bones dimensions), have been compared for a sex identification purposes. Bones from distal extremities are not useful for this purpose as they have not yet been studied in sufficient quantities, similar as metapodials.

Finally, pathological features and bite marks were observed on the historical material from the Zoolithen Cave in Germany, stored in the Natural History Museum of the
Humboldt University, Berlin (MB) and at the University of Erlangen (UE), as well as in material from the Sloup Cave. The pathological features and bite marks indicate interspecific and intraspecific aggression, thus providing important clues for understanding the palaeoecology of steppe lions and their relationships to hyenas and cave bears during the Late Pleistocene of Eurasia.

\section{Systematic palaeontology}

Order Carnivora Bowdich, 1821

Family Felidae Fischer, 1817

Subfamily Pantherinae Pocock, 1917

\section{Genus Panthera Oken, 1816}

Panthera leo spelaea (Goldfuss, 1810)

Figures 1, 4-10, 12

\section{Skeleton 1, Sloup Cave (Vienna)}

The Vienna skeleton is a composite skeleton made up of bones from different animals. It includes bones from male and female animals as well as several casts of bones (Fig. 3A). Some phalanges from the Výpustek Cave (marked "Vý" or "Výpustek"; $c f$. Fig. 4J, O) have also been included in the pedal skeleton. Most of the large bones and the skull of this skeleton seem to be from males, possibly derived from an articulated male skeleton found in the Cut-Stone Gallery of the Sloup Cave in historic times, while many of the remaining bones are either casts or from females.

Skull. - The skull is original and fairly complete, with a total length of $390 \mathrm{~mm}$ ( $c f$. Figs 1A, 4D, E), but it is missing several teeth such as both $\mathrm{P}^{2}, \mathrm{M}^{1}$, and the left $\mathrm{I}^{3}$. Only the root of the right $\mathrm{I}^{2}$ is preserved, the tip having been flaked during the animal's lifetime. The $\mathrm{P}^{3}$ length is $28 \mathrm{~mm}$ and the $\mathrm{P}^{4}$ length is $41 \mathrm{~mm}$. The teeth are hardly worn and the skull sutures are fused in the brain-case but not in the nasals, proving this to have been an adult individual 3-8 years old. A bite mark is present on the saggital crest (Fig. 4E). The lower jaws are possibly from the same skull; the left mandible has a total length of $256 \mathrm{~mm}$ and the left $\mathrm{P}_{4}$ tooth has a length of $31 \mathrm{~mm}$.

Vertebral column and pelvis. - The first two cervical vertebrae (atlas, axes) are original; the C3-6, and T1-2 are casts. The T3 up to the L4 (lumbar vertebrae, $c f$. Fig. 4L) are originals, such as the L7, but all other vertebrae are moulds. Eight of the caudal vertebrae are original bones (Fig. 4M), of which the first seven are articulated in anatomic correct row 
Table 1. Bones of the adult female Panthera leo spelaea skeleton from the hyena den Srbsko Chlum-Komín cave site (Czech Republic, Bohemian Karst).

\begin{tabular}{|c|c|c|c|c|c|c|}
\hline No. & Coll.-No. & Bone type & Commentary & Left & Right & Collection \\
\hline 1 & R 4406 & Cranium & Incomplete, without both P2 and M1 & & & NMP \\
\hline 2 & R 4407/4408 & Lower jaws & Incomplete, without I1 & $\mathrm{x}$ & $\mathrm{x}$ & NMP \\
\hline 3 & R 4415 & Scapula & Incomplete & & $\mathrm{x}$ & NMP \\
\hline 4 & $\operatorname{Ra} 4233$ & Scapula & Incomplete & $\mathrm{x}$ & & NMP \\
\hline 5 & R 4417 & Humerus & Complete & & $\mathrm{x}$ & NMP \\
\hline 6 & R 4522 & Humerus & Complete & $\mathrm{x}$ & & NMP \\
\hline 7 & R 4418 & Ulna & Complete & & $\mathrm{x}$ & NMP \\
\hline 8 & R 4419 & Ulna & Complete & $\mathrm{x}$ & & NMP \\
\hline 9 & R 4420 & Radius & Nearly complete & & $\mathrm{x}$ & NMP \\
\hline 10 & R 4421 & Radius & Complete & $\mathrm{x}$ & & NMP \\
\hline 11 & R 4605 & Scapholunatum & Complete & & $\mathrm{x}$ & NMP \\
\hline 12 & R 4606 & Scapholunatum & Complete & $\mathrm{x}$ & & NMP \\
\hline 13 & R 4621 & Pisiform & Nearly complete & & $\mathrm{x}$ & NMP \\
\hline 14 & R 4934 & Pisiform & Nearly complete & $\mathrm{x}$ & & NMP \\
\hline 15 & R 4219 & Scaphoulnar & Complete & $\mathrm{x}$ & & NMP \\
\hline 16 & R 5150 & Metacarpus & V, complete & $\mathrm{x}$ & & NMP \\
\hline 17 & R 5149 & Metacarpus & IV, complete & $\mathrm{x}$ & & NMP \\
\hline 18 & R 5031 & Metacarpus & I, complete & $\mathrm{x}$ & & NMP \\
\hline 19 & R 5148 & Metacarpus & III, complete & & $\mathrm{x}$ & NMP \\
\hline 20 & R 4535 & Metacarpus & IV, complete & & $\mathrm{x}$ & NMP \\
\hline 21 & R 4536 & Metacarpus & V, complete & & $\mathrm{x}$ & NMP \\
\hline 22 & R 4628 & Phalanx & I, manus, digit V & & $\mathrm{x}$ & NMP \\
\hline 23 & R 5029 & Phalanx & I, manus, digit V & $\mathrm{x}$ & & NMP \\
\hline 24 & R 4932 & Phalanx & I, manus, digit IV & & $\mathrm{x}$ & NMP \\
\hline 25 & R 4544 & Phalanx & I, manus, digit III & & $\mathrm{x}$ & NMP \\
\hline 26 & R 4920 & Phalanx & I, manus, digit III & $\mathrm{x}$ & & NMP \\
\hline 27 & R 4626 & Phalanx & I, manus, digit I & $\mathrm{x}$ & & NMP \\
\hline 28 & R 4935 & Phalanx & II, manus, digit V & & $\mathrm{x}$ & NMP \\
\hline 29 & R 4930 & Phalanx & II, manus, digit IV & & $\mathrm{x}$ & NMP \\
\hline 30 & R 4545 & Phalanx & II, manus, digit III & & $\mathrm{x}$ & NMP \\
\hline 31 & R 4927 & Phalanx & II, manus, digit III & $\mathrm{x}$ & & NMP \\
\hline 32 & R 4928 & Phalanx & II, manus, digit II & $\mathrm{x}$ & & NMP \\
\hline 33 & R 4626 & Phalanx & II, manus, digit I & $\mathrm{x}$ & & NMP \\
\hline 34 & R 4933 & Phalanx & III, manus, ?digit IV & & $\mathrm{x}$ & NMP \\
\hline 35 & R 4625 & Phalanx & III, manus, ?digit III & & $\mathrm{x}$ & NMP \\
\hline 36 & R 5153 & Phalanx & III, manus, ?digit IV & $\mathrm{x}$ & & NMP \\
\hline 37 & R 4926 & Phalanx & III, manus, ?digit V & & $\mathrm{x}$ & NMP \\
\hline 38 & $\mathrm{R} 4523 / 4224 / 4565$ & Pelvic & Nearly complete, with sacrum & & & NMP \\
\hline 39 & R 4525 & Femur & Nearly complete & & $\mathrm{x}$ & NMP \\
\hline 40 & R 4526 & Femur & Nearly complete & $\mathrm{x}$ & & NMP \\
\hline 41 & R 4602 & Patella & Complete & & $\mathrm{x}$ & NMP \\
\hline 42 & R 4533 & Patella & Complete & $\mathrm{x}$ & & NMP \\
\hline 43 & R 4528 & Tibia & Nearly complete & & $\mathrm{x}$ & NMP \\
\hline 44 & R 4527 & Tibia & Complete & $\mathrm{x}$ & & NMP \\
\hline 45 & R 4607 & Fibula & Without proximal joint & & $\mathrm{x}$ & NMP \\
\hline 46 & R 4532 & Fibula & Half with distal joint & $\mathrm{x}$ & & NMP \\
\hline 47 & R 4530 & Calcaneus & Complete & $\mathrm{x}$ & & NMP \\
\hline 48 & R 4914 & Astragal & Complete & & $\mathrm{x}$ & NMP \\
\hline 49 & R 4531 & Astragal & Complete & $\mathrm{x}$ & & NMP \\
\hline 50 & R 4937 & Cuboid & Complete & $\mathrm{x}$ & & NMP \\
\hline
\end{tabular}


Table 1. continued

\begin{tabular}{|c|c|c|c|c|c|c|}
\hline No. & Coll.-No. & Bone type & Commentary & Left & Right & Collection \\
\hline 51 & R 4635 & Navicular & Complete & $\mathrm{x}$ & & NMP \\
\hline 52 & Ra 4232 & Tarsal II & Half & $\mathrm{x}$ & & NMP \\
\hline 53 & R 4539 & Metatarsus & $\mathrm{V}$, complete & & $\mathrm{x}$ & NMP \\
\hline 54 & R 4538 & Metatarsus & IV, complete & & $\mathrm{x}$ & NMP \\
\hline 55 & $\mathrm{Ra} 4231$ & Metatarsus & III, proximal joint, fragment & & $\mathrm{x}$ & NMP \\
\hline 56 & R 4537 & Metatarsus & II, complete & & $\mathrm{x}$ & NMP \\
\hline 57 & $\mathrm{R} 4543$ & Metatarsus & $\mathrm{V}$, complete & $\mathrm{x}$ & & NMP \\
\hline 58 & R 4542 & Metatarsus & IV, complete & $\mathrm{x}$ & & NMP \\
\hline 59 & R 4541 & Metatarsus & III, complete & $\mathrm{x}$ & & NMP \\
\hline 60 & $\mathrm{R} 4540$ & Metatarsus & II, complete & $\mathrm{x}$ & & NMP \\
\hline 61 & R 5038 & Phalanx & I, pes, digit $\mathrm{V}$ & & $\mathrm{x}$ & NMP \\
\hline 62 & R 4919 & Phalanx & I, pes, digit IV & $\mathrm{x}$ & & NMP \\
\hline 63 & R 4632 & Phalanx & I, pes, digit III & & $\mathrm{x}$ & NMP \\
\hline 64 & R 4627 & Phalanx & I, pes, digit II & & $\mathrm{x}$ & NMP \\
\hline 65 & R 4922 & Phalanx & I, pes, ?digit & $\mathrm{x}$ & & NMP \\
\hline 66 & R 5030 & Phalanx & II, pes, digit II & $\mathrm{x}$ & & NMP \\
\hline 67 & R 4942 & Phalanx & II, pes, ?digit & & $\mathrm{x}$ & NMP \\
\hline 68 & R 4929 & Phalanx & II, pes, digit IV & & $\mathrm{x}$ & NMP \\
\hline 69 & R 4633 & Phalanx & II, pes, digit III & & $\mathrm{x}$ & NMP \\
\hline 70 & R 5154 & Phalanx & II, pes, ?digit IV & & $\mathrm{x}$ & NMP \\
\hline 71 & R 4624 & Phalanx & III, pes, ?digit II & $\mathrm{x}$ & & NMP \\
\hline 72 & R 4923 & Phalanx & III, pes, ?digit III & $\mathrm{x}$ & & NMP \\
\hline 73 & R 5151 & Phalanx & III, pes, ?digit IV & $\mathrm{x}$ & & NMP \\
\hline 74 & R 4924 & Phalanx & III, pes, ?digit V & $\mathrm{x}$ & & NMP \\
\hline 75 & R 5152 & Phalanx & III, pes, ?digit III & & $\mathrm{x}$ & NMP \\
\hline 76 & R 4630 & Phalanx & III, pes, ?digit V & & $\mathrm{x}$ & NMP \\
\hline 77 & R 4409 & Cervical vertebra & Atlas, incomplete & & & NMP \\
\hline 78 & R 4410 & Cervical vertebra & Axis, incomplete & & & NMP \\
\hline 79 & R 5032 & Cervical vertebra & No. 3, incomplete & & & NMP \\
\hline 80 & R 4414 & Cervical vertebra & No. 4 , incomplete & & & NMP \\
\hline 81 & R 4411 & Cervical vertebra & No. 5 , incomplete & & & NMP \\
\hline 82 & R 4412 & Cervical vertebra & No. 6, incomplete & & & NMP \\
\hline 83 & R 4413 & Cervical vertebra & No. 7, incomplete & & & NMP \\
\hline 84 & R 4548 & Thoracic vertebra & No. 1 , complete & & & NMP \\
\hline 85 & R 4549 & Thoracic vertebra & No. 2, incomplete & & & NMP \\
\hline 86 & R 4551 & Thoracic vertebra & No. 3 , incomplete & & & NMP \\
\hline 87 & $\mathrm{Ra} 4214$ & Thoracic vertebra & No. ?, Proc. spinosus & & & NMP \\
\hline 88 & R 4550 & Thoracic vertebra & No. ?, incomplete & & & NMP \\
\hline 89 & R 4552 & Thoracic vertebra & No. ?, incomplete & & & NMP \\
\hline 90 & R 4553 & Thoracic vertebra & No. 9, incomplete & & & NMP \\
\hline 91 & R 4555 & Thoracic vertebra & No. 10 , incomplete & & & NMP \\
\hline 92 & R 4554 & Thoracic vertebra & No. 11 , complete & & & NMP \\
\hline 93 & R 4556 & Thoracic vertebra & No. 12 , incomplete & & & NMP \\
\hline 94 & R 4557 & Thoracic vertebra & No. 13 , complete & & & NMP \\
\hline 95 & R 4558 & Thoracic vertebra & No. 14 , incomplete & & & NMP \\
\hline 96 & R 4559 & Lumbar vertebra & No. 1 , complete & & & NMP \\
\hline 97 & Ra 4229 & Lumbar vertebra & No.2, two fragments & & & NMP \\
\hline 98 & R 4561 & Lumbar vertebra & No. 3 , incomplete & & & NMP \\
\hline 99 & $\mathrm{Ra} 4230 \mathrm{a}$ & Lumbar vertebra & ?No. 4 , fragment & & & NMP \\
\hline 100 & $\mathrm{Ra} 4230 \mathrm{~b}$ & Lumbar vertebra & ?No. 4, fragment & & & NMP \\
\hline
\end{tabular}


Table 1. continued

\begin{tabular}{|c|c|c|c|c|c|}
\hline No. Coll.-No. & Bone type & Commentary & Left & Right & Collection \\
\hline $101 \mathrm{Ra} 4230 \mathrm{c}$ & Lumbar vertebra & ?No. 5, 2 fragments & & & NMP \\
\hline 102 R 4563 & Lumbar vertebra & No. 6, incomplete & & & NMP \\
\hline 103 R 4564 & Lumbar vertebra & No. 7, incomplete & & & NMP \\
\hline 104 R 4566 & Caudal vertebra & No. ?, upper, incomplete & & & NMP \\
\hline 105 R 4567 & Caudal vertebra & No. ?, upper, complete & & & NMP \\
\hline $106 \mathrm{R} 4568$ & Caudal vertebra & No. ?, upper, incomplete & & & NMP \\
\hline 107 R 4569 & Caudal vertebra & No. ?, upper, complete & & & NMP \\
\hline 108 R 4570 & Caudal vertebra & No. ?, middle, complete & & & NMP \\
\hline 109 R 4571 & Caudal vertebra & No. ?, middle, complete & & & NMP \\
\hline 110 R 4597 & Caudal vertebra & No. ?, middle, incomplete & & & NMP \\
\hline $111 \mathrm{R} 4572$ & Caudal vertebra & No. ?, middle, complete & & & NMP \\
\hline 112 R 4573 & Caudal vertebra & No. ?, lower, complete & & & NMP \\
\hline 113 R 4574 & Caudal vertebra & No. ?, lower, complete & & & NMP \\
\hline 114 R 5377 & Caudal vertebra & No. ?, lower, complete & & & NMP \\
\hline 115 R 5378 & Caudal vertebra & No. ?, lower, complete & & & NMP \\
\hline 116 R 5380 & Caudal vertebra & No. ?, lower, complete & & & NMP \\
\hline $117 \mathrm{Ra} 4280$ & Caudal vertebra & Last two fused & & & NMP \\
\hline $118 \mathrm{Ra} 4224$ & Costa & No. 1 & & $\mathrm{x}$ & NMP \\
\hline $119 \mathrm{Ra} 4225$ & Costa & No. 2, complete & & $\mathrm{x}$ & NMP \\
\hline $120 \mathrm{Ra} 4226$ & Costa & No. 3, complete & & $\mathrm{x}$ & NMP \\
\hline $121 \mathrm{Ra} 4227$ & Costa & No. 4 & & $\mathrm{x}$ & NMP \\
\hline $122 \mathrm{Ra} 4228$ & Costa & No. 5 & & $\mathrm{x}$ & NMP \\
\hline $123 \mathrm{Ra} 4248$ & Costa & No. 6, complete & & $\mathrm{x}$ & NMP \\
\hline $124 \mathrm{Ra} 4230$ & Costa & No. 7, complete & & $\mathrm{x}$ & NMP \\
\hline $125 \mathrm{Ra} 4232$ & Costa & No. 8, complete & & $\mathrm{x}$ & NMP \\
\hline $126 \mathrm{Ra} 4233$ & Costa & No. 9 & & $\mathrm{x}$ & NMP \\
\hline $127 \mathrm{Ra} 4234$ & Costa & No. 10 , complete & & $\mathrm{x}$ & NMP \\
\hline $128 \mathrm{Ra} 4235$ & Costa & No. 11 , nearly complete & & $\mathrm{x}$ & NMP \\
\hline $129 \mathrm{Ra} 4236$ & Costa & No. 12 , complete & & $\mathrm{x}$ & NMP \\
\hline $130 \mathrm{Ra} 4237$ & Costa & No. 13, complete & & $\mathrm{x}$ & NMP \\
\hline $131 \mathrm{Ra} 4238$ & Costa & No. 1 & $\mathrm{x}$ & & NMP \\
\hline 132 Ra 4239 & Costa & No. 2 & $\mathrm{x}$ & & NMP \\
\hline 133 Ra 4240 & Costa & No. 3 & $\mathrm{x}$ & & NMP \\
\hline $134 \mathrm{Ra} 4241$ & Costa & No. 4 & $\mathrm{x}$ & & NMP \\
\hline $135 \mathrm{Ra} 4242$ & Costa & No. 5 & $\mathrm{x}$ & & NMP \\
\hline $136 \mathrm{Ra} 4243$ & Costa & No. 6 & $\mathrm{x}$ & & NMP \\
\hline $137 \mathrm{Ra} 4244$ & Costa & No. 7 & $\mathrm{x}$ & & NMP \\
\hline $138 \mathrm{Ra} 4245$ & Costa & No. 8 & $\mathrm{x}$ & & NMP \\
\hline 139 Ra 4246 & Costa & No. 9 & $\mathrm{x}$ & & NMP \\
\hline $140 \mathrm{Ra} 4247$ & Costa & No. 10 & $\mathrm{x}$ & & NMP \\
\hline $141 \mathrm{Ra} 4249$ & Costa & No. 11 & $\mathrm{x}$ & & NMP \\
\hline $142 \mathrm{Ra} 4250$ & Costa & No. 12 & $\mathrm{x}$ & & NMP \\
\hline $143 \mathrm{Ra} 4251$ & Costa & No. 13 & $\mathrm{x}$ & & NMP \\
\hline $144 \mathrm{Ra} 4252$ & Sternal bone & No. 1 & & & NMP \\
\hline $145 \mathrm{Ra} 4253$ & Sternal bone & No. ?2 & & & NMP \\
\hline $146 \mathrm{Ra} 4220$ & Sesamoid & Complete & & & NMP \\
\hline $147 \mathrm{Ra} 4221$ & Sesamoid & Complete & & & NMP \\
\hline $148 \mathrm{Ra} 4222$ & Sesamoid & Complete & & & NMP \\
\hline $149 \mathrm{Ra} 4223$ & Sesamoid & Complete & & & NMP \\
\hline
\end{tabular}


(possibly from one individual). The positions of one central and one distal caudal vertebrae are uncertain. The coxa is $363 \mathrm{~mm}$ long and has an acetabulum diameter of $50 \mathrm{~mm}$; the sacrum of the pelvis is a mould. The right ribs include one from a cub (most probably from a cave bear) with a non-fused head (the $13^{\text {th }}$ rib). All of the other preserved ribs, i.e. the $5^{\text {th }}, 7^{\text {th }}, 9^{\text {th }}$ (with pathological feature, Fig. $4 \mathrm{~K}$ ) $10^{\text {th }}, 11^{\text {th }}$ and $12^{\text {th }}$, have fused rib heads. The left ribs have partly been preserved (Nos. 1, 2, 4, 6, 8, and 11); others are casts, as are all sternal bones.

Appendicular skeleton. - The right scapula is complete (length $312 \mathrm{~mm}$, glenoid width $68 \mathrm{~mm}$, Fig. 4F) but the left scapula is a cast. Both large humeri are similarly proportioned and preserved (length $380 \mathrm{~mm}$, distal width $100 \mathrm{~mm}$, Fig. 4G, H). Neither ulna is original and only the large right radius is complete (with male proportions: length $340 \mathrm{~mm}$, distal width $75 \mathrm{~mm}$, Fig. 4I). All five right metacarpi are originals (Fig. 4J), while the left metacarpi have a cast of the Mc I. The different proportions and lack of symmetry between left and right metacarpals suggest a mixed derivation from both male and female specimens which, in some cases, may have even derived from different caves (i.e. the Sloup and Výpustek caves; $c f$. Fig. 4J). All original carpalia in the right manus are missing and only represented by casts while in the left manus the scapholunatae, and probably also the metacarpal bones, are originals. In both forelimb manus skeletons some of the phalanges I-III are casts. The hind limbs have two large symmetrical femora (length $425 \mathrm{~mm}$, distal width $90 \mathrm{~mm}$ ) and one large right tibia (length $364 \mathrm{~mm}$, distal width $68 \mathrm{~mm}$, Fig. 4N). Both original calcanei are symmetrical and large (128 $\mathrm{mm}$ in length). Once again, the metatarsals and phalanges do not originate from a single individual or a single cave site. Whereas most bones are originals, the Mt I is a cast (Fig. 4O).

\section{Skeleton 2, Sloup Cave (Brno)}

The skull of this skeleton is a compilation, with at least one mandible derived from a different source; the front legs are less then $50 \%$ made up of original bones, and those in the hind legs originate from both males and females. It is unclear which parts might have belonged to the original skeleton because it is such a complete mixture, including material from different skeletons (including both males and females) from the Cut-Stone Gallery of the Sloup Cave, and there are even more casts than in skeleton 1 (Vienna).

Skull. - The original skull (Fig. 4A) has a total length of $357 \mathrm{~mm}$ and is missing some of the original teeth. On the right and left it lacks the small $\mathrm{M}^{1}$, whereas the left side canine tooth is a much too short cast. The frontal width is $98 \mathrm{~mm}$; the left $\mathrm{P}^{4}$ length is $36 \mathrm{~mm}$. The lower jaw appears

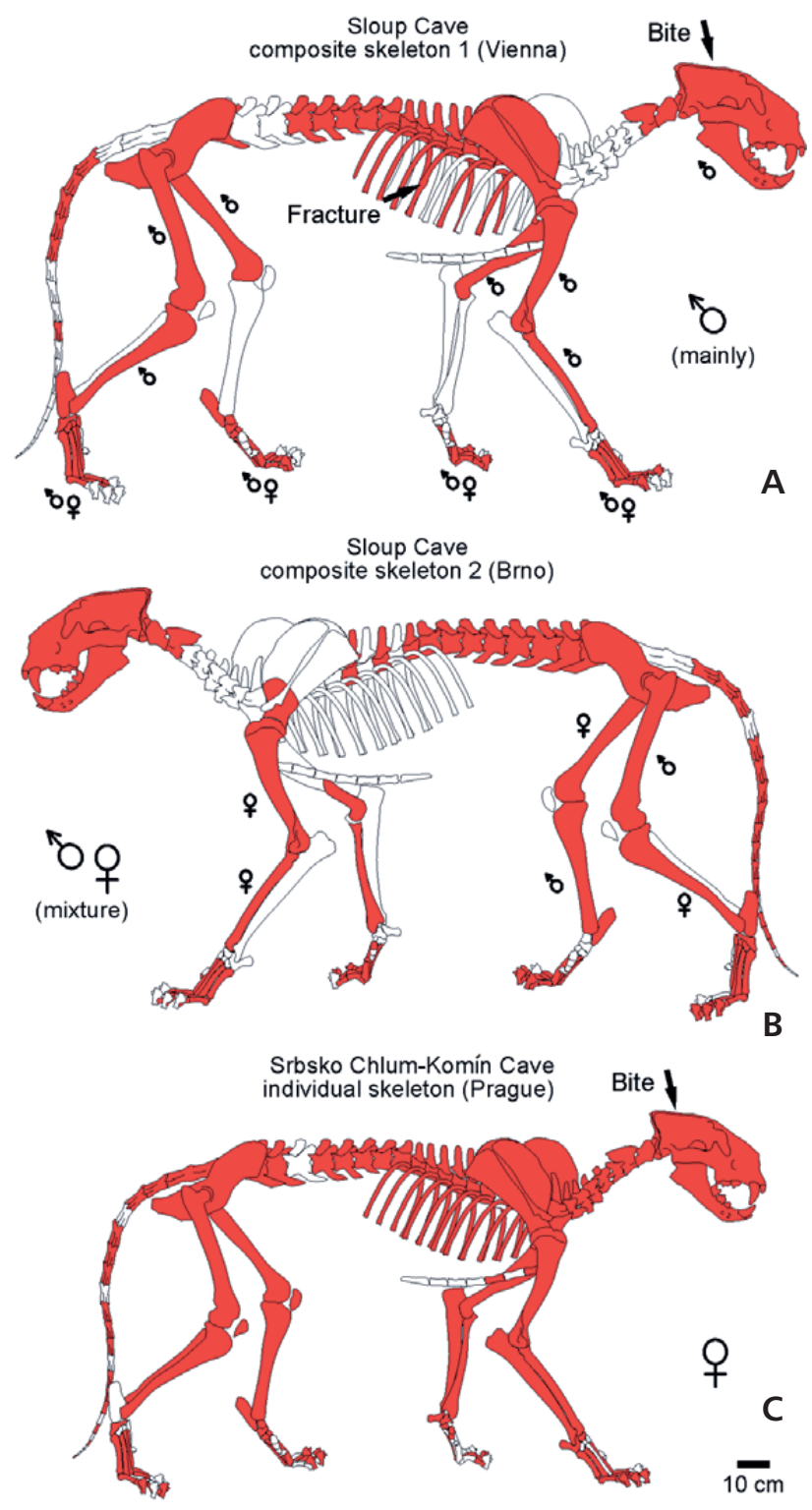

Figure 3. Composite and "real" skeletons of the Late Pleistocene steppe lion Panthera leo spelaea (Goldfuss, 1810) from Czech Republic cave sites. A - composite skeleton 1 with bones from the Sloup Cave, in the Natural History Museum, Vienna (NHMV No. 1885/0014/4302, cf. Fig. 1A). • B - composite skeleton 2 with bones from the Sloup Cave, on display in the Anthropos Museum, Brno (AMB without No.). $\bullet \mathrm{C}-$ single skeleton from the Srbsko Chlum-Komín Cave, in the Natural History Museum, Prague (NMP No. R 4406) (red = original bones, white = casts).

to be a composite from more than one original. The right mandible, with its complete dentition, is consistent with a young adult animal skull in which the anterior parts are non-fused, but the brain-case bones are fused. The left mandible is from an older, senile individual, with an $\mathrm{M}_{1}$ that is highly worn, as are also the $\mathrm{P}_{3-4}$ teeth.

Vertebral column and pelvis. - The atlas has been mounted the wrong way round; the axis vertebra is an original. All 


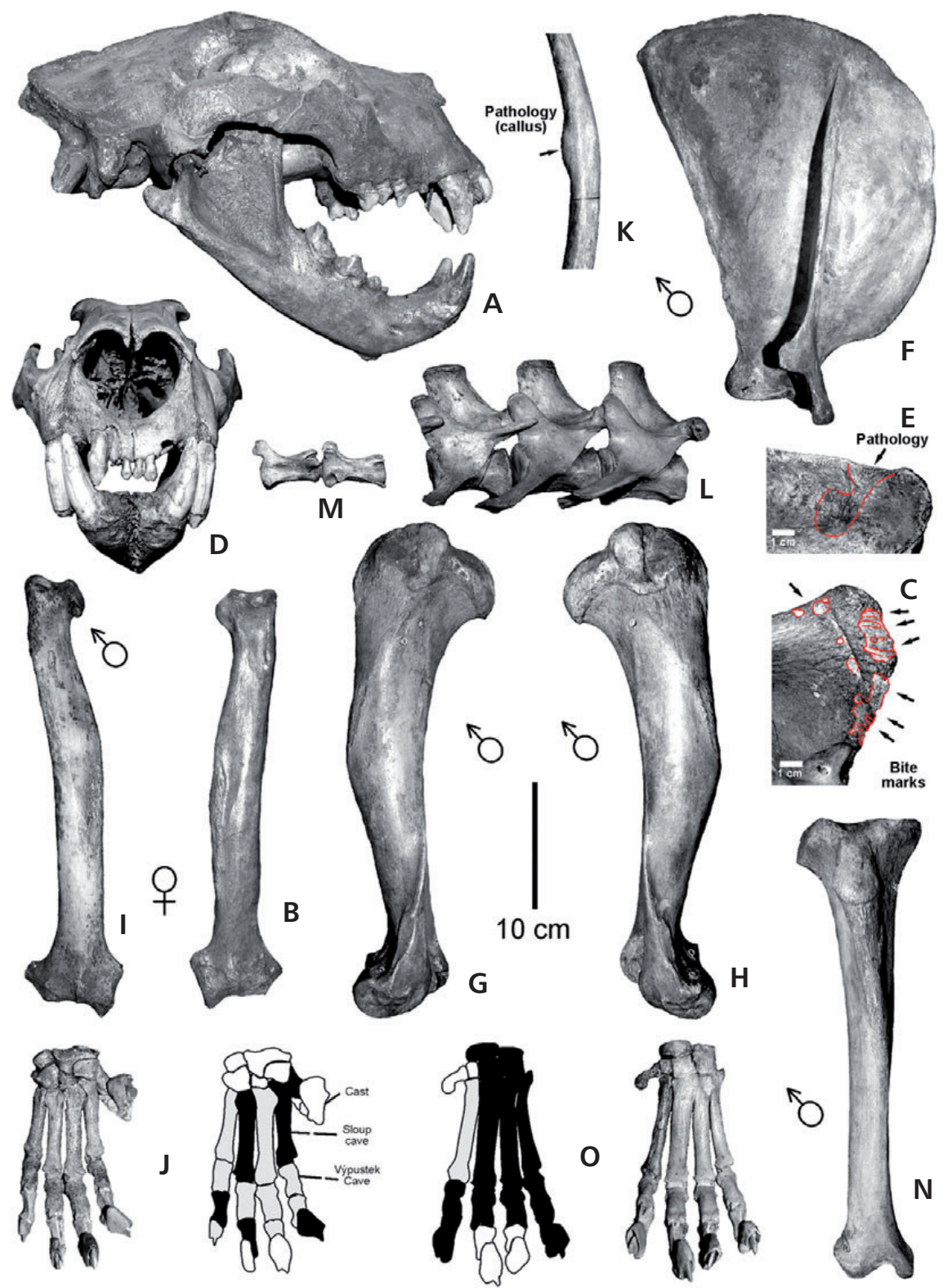

Figure 4. Selected bones from skeletons 1 and 2 of the Late Pleistocene lion Panthera leo spelaea (Goldfuss, 1810), from the CutStone Gallery of the Sloup Cave, Moravian Karst (Czech Republic). • A - skeleton 2 (Brno) skull (cf. Fig. 1A), lateral. • B - skeleton 2 (Brno) left radius, lateral. $\bullet \mathrm{C}$ - skeleton 2 (Brno) pelvis with large carnivore bite marks ( $c f$. Fig. 3). • D - skeleton 1 (Vienna) skull, frontal. $\bullet \mathrm{E}$ - skeleton 1 (Vienna) skull, detail of the pathology on the left side of the brain-case ( $c f$. also Fig. 12B), lateral left. - F - skeleton 1 (Vienna) right scapula, lateral. $\bullet \mathrm{G}$ - skeleton 1 (Vienna) left humerus, lateral. • H - skeleton 1 (Vienna) right humerus, lateral. $\bullet$ I - skeleton 1 (Vienna) right radius, lateral. $\bullet \mathrm{J}$ - skeleton 1 (Vienna) right composite manus skeleton, cranial. $\bullet \mathrm{K}-$ skeleton 1 (Vienna) middle rib with pathology, lateral. - L - skeleton 1 (Vienna) middle lumbar vertebrae, lateral. - M - skeleton 1 (Vienna) middle caudal vertebrae, lateral. - $\mathrm{N}$ - skeleton 1 (Vienna) right tibia, cranial. - O - skeleton 1 (Vienna) composite left pes skeleton, cranial.

the cervical vertebrae are casts. The $3-7,9,11,13$ and 14 (last) thoracic vertebrae are originals, as is the entire lumbar vertebral column L1-7 which may thus have derived from a single individual. Sixteen of the caudal vertebrae are originals but the distal vertebrae are casts. None of the ribs are original; all of the sternal bones are missing.

Appendicular skeleton. - The left scapula is not original but a fragment (including the glenoid) is preserved from the right scapula. The left humerus is complete and $362 \mathrm{~mm}$ long, while only the distal half of the right humerus is preserved (distal width $92 \mathrm{~mm}$ ). The left radius is missing the anterior joint but the right radius is complete (length 324 mm, Fig. 4B). Both ulnae are casts, as are most of the carpals. The left manus has the original pisiform, and possibly one other original carpal bone. The metapodials in the manus skeletons are composites that appear to all be from the right hand side, with the Mc II-V having been derived from a single individual. All phalanges I-II are originals, as are three phalanges III - the fourth is a cast. The right manus again has original Mc II-V metapodials, as are all phalanges I-II, but only the middle two phalanges III are bones, the outer phalanges are casts. The hind limbs are in both cases made up of original femora and tibiae bones but they are not symmetrical and do not have the same proportions, suggesting that they do not come from a single individual. The left femur is longer $(440 \mathrm{~mm})$ than the right femur $(380 \mathrm{~mm})$. In contrast, the right tibia is only $345 \mathrm{~mm}$ long, the left one is $362 \mathrm{~mm}$, proving these to be composites made up of both male and female hind limb bones. The 


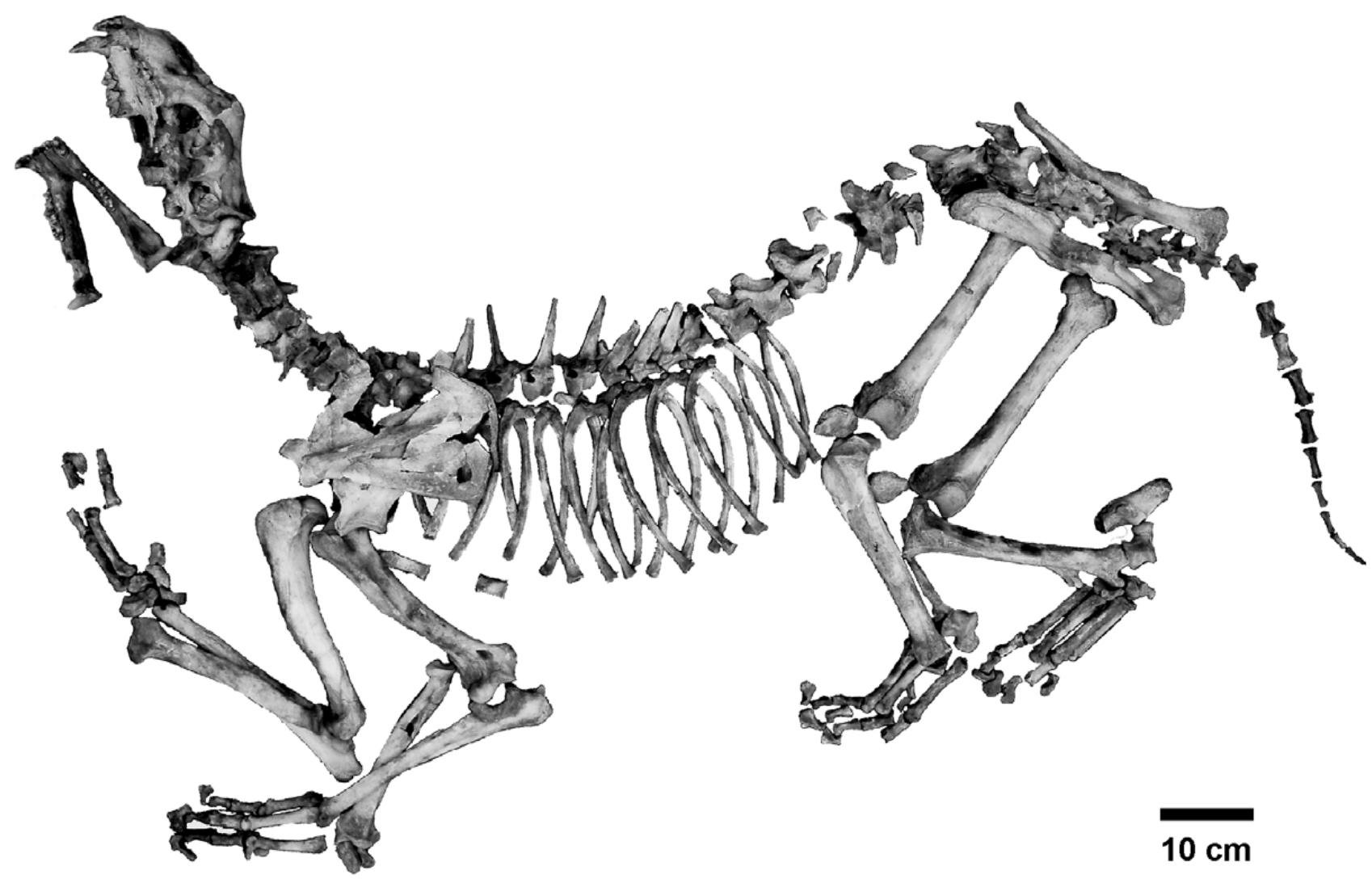

Figure 5. The articulated and almost complete skeleton 3 of the steppe lion Panthera leo spelaea (Goldfuss, 1810) from the Srbsko Chlum-Komín Cave (NMP No. R 4406). The pathologically damaged brain-case was in the process of healing (after Diedrich \& Žák 2006).

feet are incorrectly mounted. The right calcaneus has proximal bite marks and is incomplete, while the left calcaneus is complete. The left pes skeleton has all tarsalia, the Mt II-V, phalanges I-II, and three phalanges III; the inner phalanx III is a cast. The missing digit I has not even been reproduced on either foot. The right pes skeleton consists of all tarsalia, the Mt II-V, 3 phalanx I and all phalanx II; within the phalanx III one digit II is a cast. All the phalanges of the pedal skeletons seem to be composites and often phalanx II is in the wrong position, as are some of the other phalanges.

\section{Skeleton 3, Srbsko Chlum-Komín Cave (Prague)}

This skeleton has 149 bones that belong to the original skeleton of a young adult lioness (Fig. 5, Table 1), whereas the phalange III and some phalange II may, in some cases, have derived from a second skeleton of a juvenile animal. The distal extremity bones (starting from the metapodials) are therefore not illustrated herein. All other non-pedal bones have larger dimensions and belong to the original skeleton illustrated herein of a young adult lioness. No scavenging marks are present on the bones. Many modern fractures are present and some pieces of bone are missing, all of which are the result of careless excavation. Evidence that the bone material is from a single individual is provided by the symmetry of the skeleton, the consistent proportions, and the lack of any repetition in the bones. The origin of the small pedal bones (phalanges) is more problematic and these may have come from a second, juvenile skeleton.

Skull. - In many of the views illustrated herein the cranium with lower jaw (Fig. 6) can be seen to be extensively damaged. Both upper jaw $\mathrm{P}^{2}$ are missing, as is the left $\mathrm{M}^{1}$. The incisors, both canines, and the $\mathrm{P}^{3-4}$ are in their alveoli. The nasal bones and front of the skull have been damaged. The lower jaw (Fig. 6F, G) has been badly damaged but both mandibles fit together exactly in their symphyses. The right mandible includes the $\mathrm{I}_{2-3}, \mathrm{C}$, and $\mathrm{P}_{3-4}$; the left mandible has no incisors in its alveoli. Both mandibles are incomplete in the vicinity of the ramus. One more isolated fragment belongs to this jaw. The important mandible measurements for sex identification are listed in Table 2 for the more complete right mandible. The teeth in both upper and lower jaws are similarly unworn and unpolished.

Vertebral column and pelvis. - Many of the 39 vertebrae preserved (Fig. 7; Table 1) are almost complete, but also 

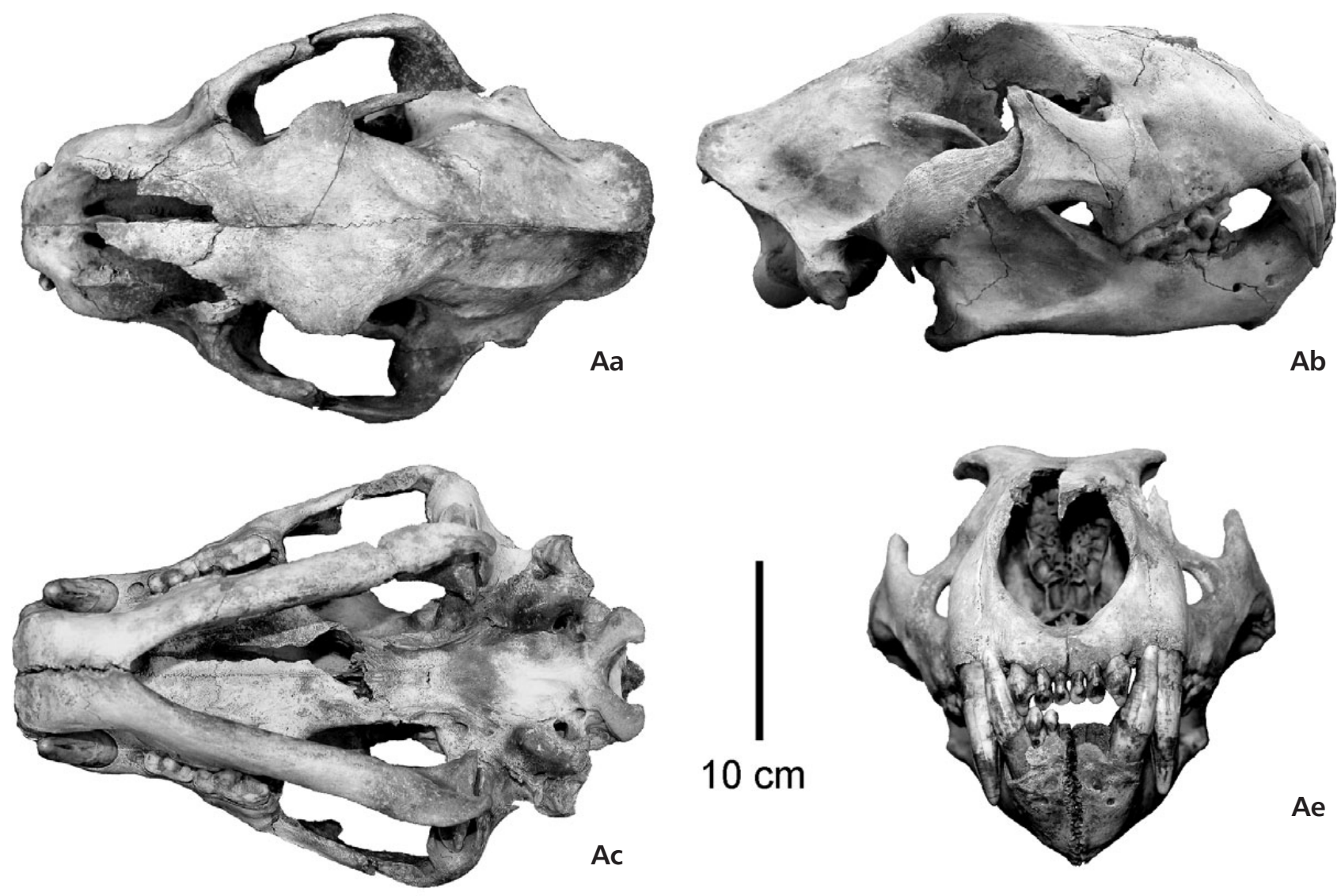

Ae
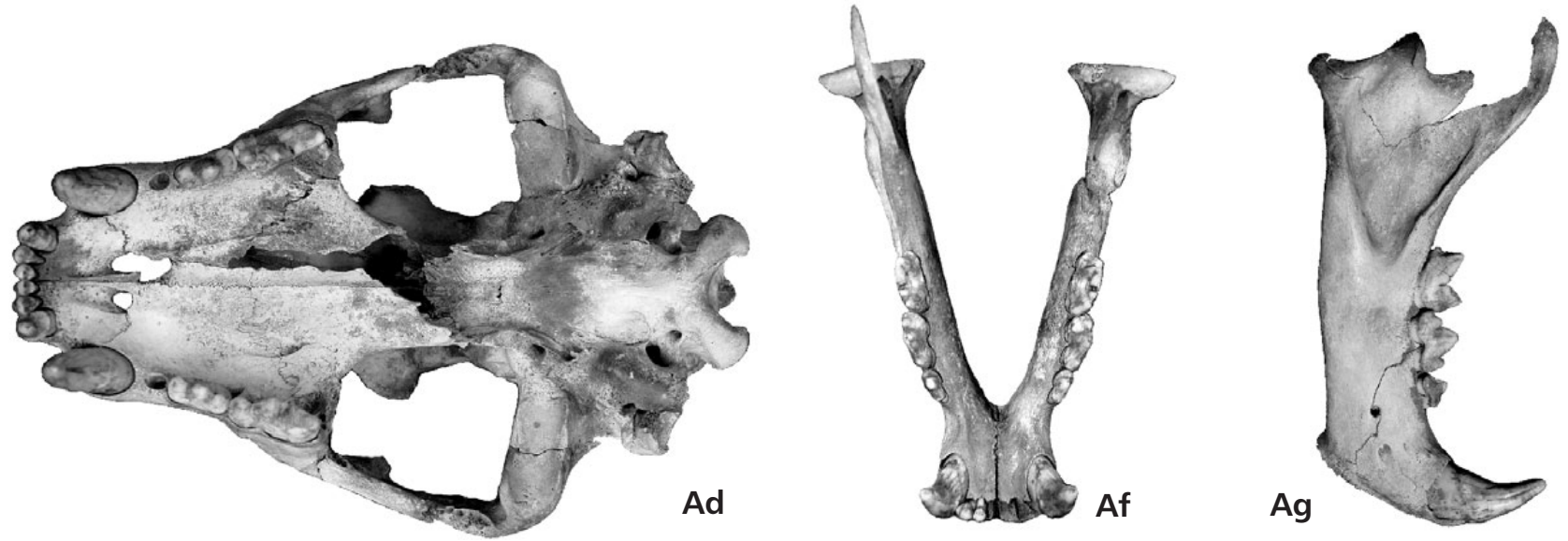

Figure 6. Cranium of the young adult lioness Panthera leo spelaea (Goldfuss, 1810) skeleton (skeleton 3) from the Srbsko Chlum-Komín Cave of the Bohemian Karst (Czech Republic). • A - skull with mandible dorsal, B - skull with mandible lateral right, C - skull with mandible ventral, D - skull ventral, E - skull frontal, F - mandible dorsal, G - mandible lateral right (NMP No. R 4406).

Figure 7. Vertebral column of the young adult lioness Panthera leo spelaea (Goldfuss, 1810) skeleton (skeleton 3) from the Srbsko Chlum-Komín Cave of the Bohemian Karst (Czech Republic). • A - first cervical vertebra, atlas (NMP No. R 4409), a - cranial, b - dorsal. • B - second cervical vertebra, axes (NMP No. R 4410), a - dorsal, b - lateral. $\bullet$ C - third cervical vertebra (NMP No. R 5032), a - cranial, b - dorsal. $\bullet$ D - fourth cervical vertebra (NMP No. R 4414), a - cranial, b - dorsal. • E - fifth cervical vertebra (NMP No. R 4411), a - cranial, b - dorsal. • F - sixth cervical vertebra (NMP No. R 4412), a - cranial, b - dorsal. $\cdot G$ - seventh cervical vertebra (NMP No. R 4413), a - cranial, b - lateral $\bullet$ H - first thoracic vertebra (NMP No. R 4548), a - cranial, b - lateral. • I - second thoracic vertebra (NMP No. R 4549), a - cranial, b - lateral. • J - third thoracic vertebra (NMP No. R 4551), a - cranial, b - lateral. 


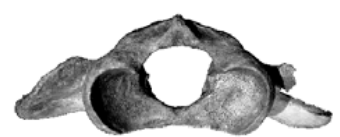

$\mathrm{Aa}$
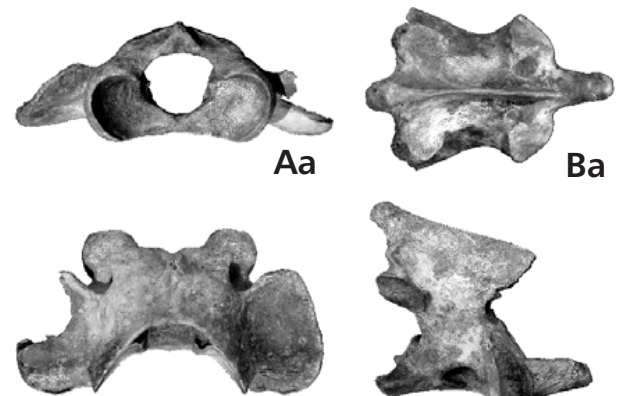

$A b$
Ba

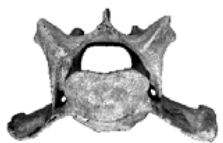

$\mathrm{Ca}$
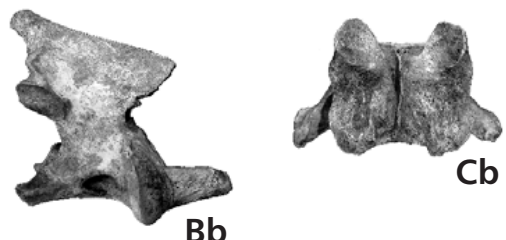

$\mathrm{Cb}$
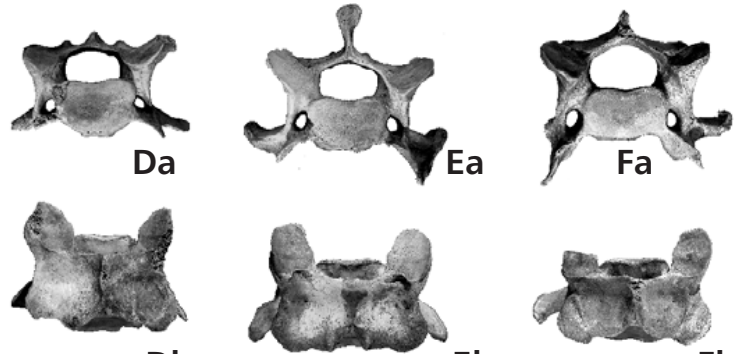

Db
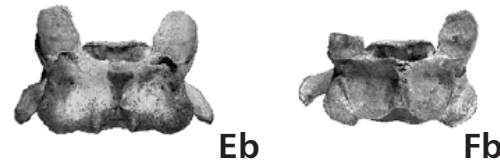
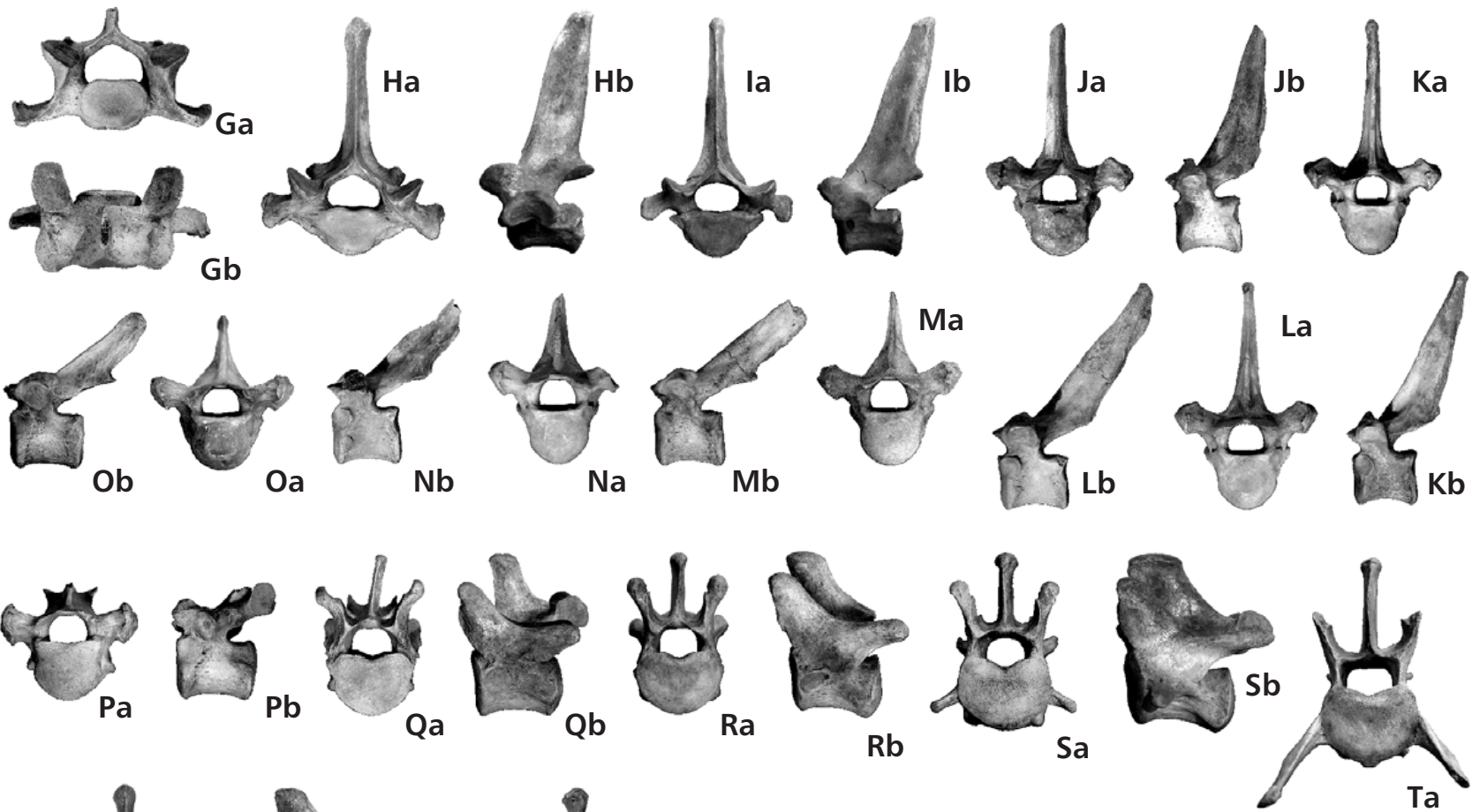

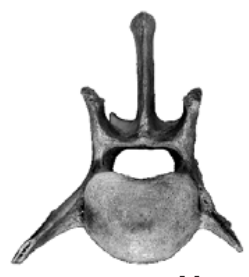

Ua

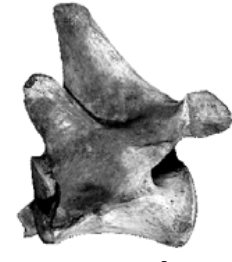

Ub
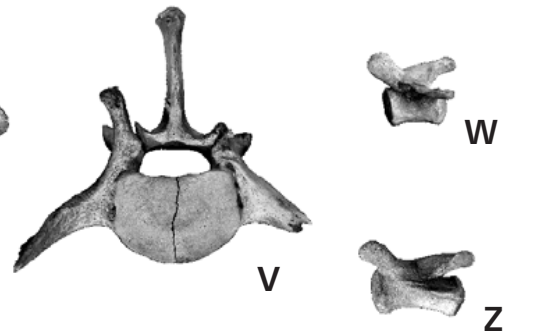
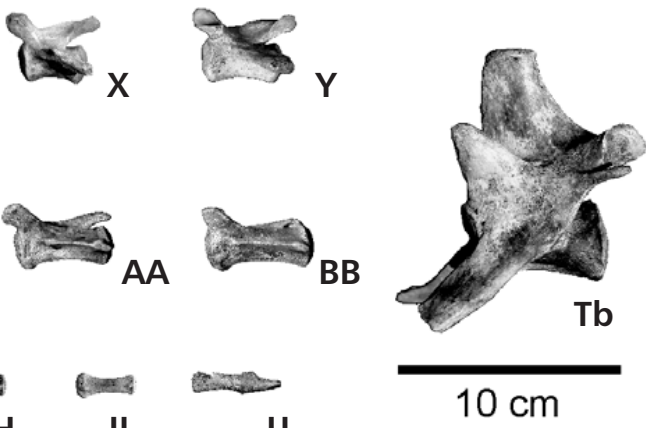
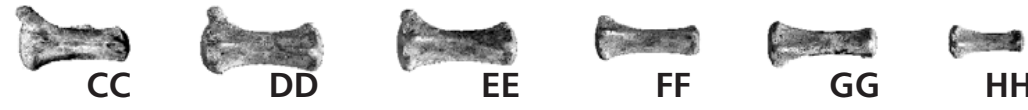

$\mathrm{HH}$

- K - 6-7 thoracic vertebra (NMP No. R 4550), a - cranial, b - lateral. $\bullet$ L - 7-8 thoracic vertebra (NMP No. R 4552), a - cranial, b - lateral. $\bullet$ M - ninth thoracic vertebra (NMP No. R 4553), a - cranial, b - lateral. $\bullet N-$ tenth thoracic vertebra (NMP No. R 4555), a - cranial, b-lateral. $\bullet O-$ eleventh thoracic vertebra (NMP No. R 4554), a - cranial, b - lateral. $\bullet$ P - twelfth thoracic vertebra (NMP No. R 4556), a - cranial, b - lateral. • Q - thirteenth thoracic vertebra (NMP No. R 4557), a - cranial, b - lateral. • R - fourteenth and last thoracic vertebra (NMP No. R 4558), a - cranial, b - lateral. $\bullet S-$ first lumbar vertebra (NMP No. R 4559), a - cranial, b - lateral. • T - third lumbar vertebra (NMP No. R 4561), a - cranial, b - lateral. • U - sixth lumbar vertebra (NMP No. R 4563), a - cranial, b - lateral. • V - seventh and last lumbar vertebra (NMP No. R 4564), a - cranial, b - lateral. • W - upper caudal vertebra (NMP No. R 4566), lateral. $\bullet X$ - upper caudal vertebra (NMP No. R 4567), lateral. • Y - upper caudal vertebra (NMP No. R 4568), lateral. $\bullet Z$ - upper caudal vertebra (NMP No. R 4569), lateral. • AA - upper caudal vertebra (NMP No. R 4570), lateral. • BB - middle caudal vertebra (NMP No. R 4571), lateral. - CC - middle caudal vertebra (NMP No. R 4597), lateral. $\bullet$ DD - middle caudal vertebra (NMP No. R 4572), lateral. • EE - middle caudal vertebra (NMP No. R 4573), lateral. $\bullet$ FF - lower caudal vertebra (NMP No. R 4574), lateral. $\bullet$ HH - lower caudal vertebra (NMP No. R 5378), lateral. • II - lower caudal vertebra (NMP No. R 5380), lateral. • JJ - last two fused lower caudal vertebrae (NMP No. Ra 4218), lateral. 


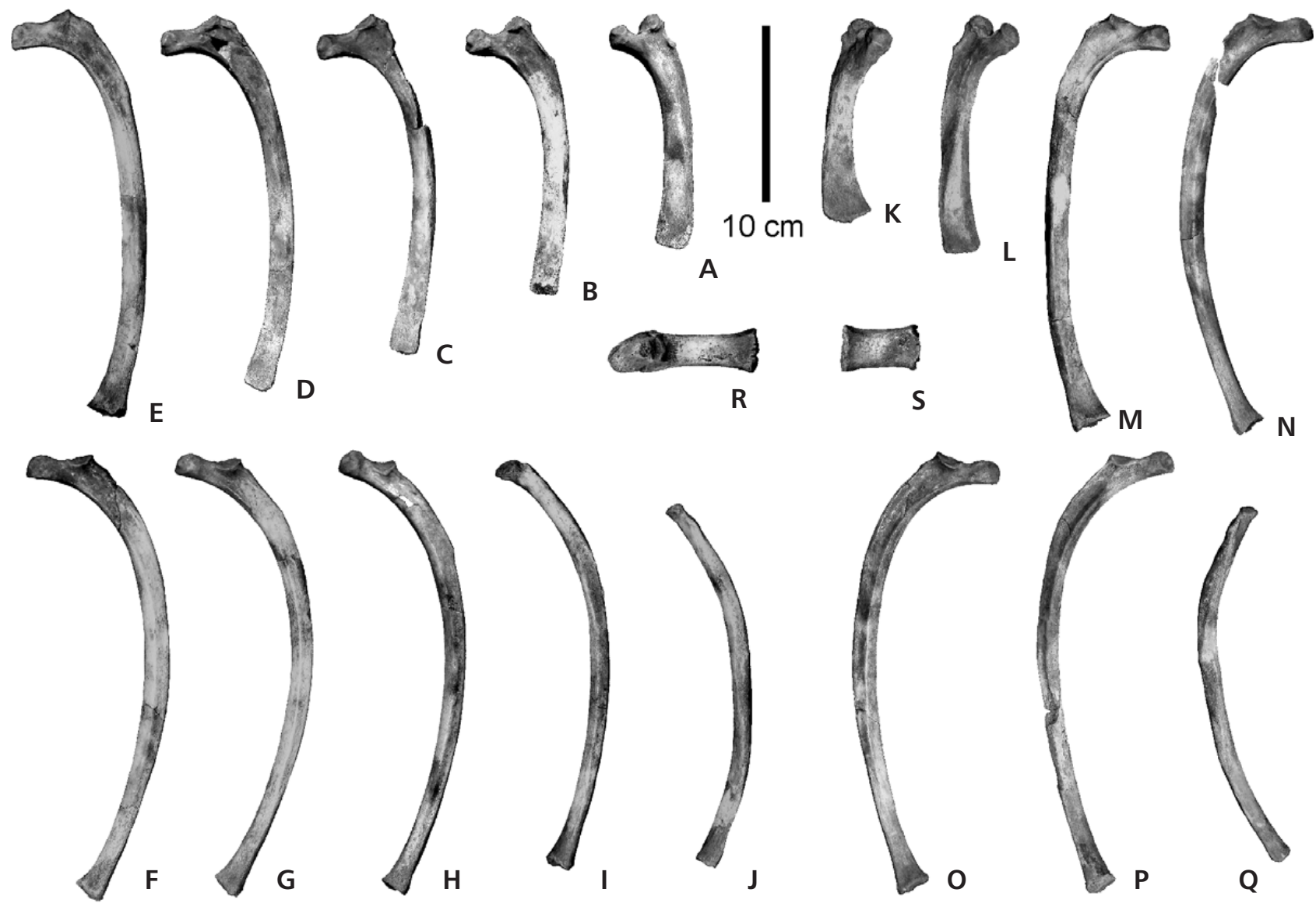

Figure 8. Thoracic costae and sternal bones of the young adult lioness Panthera leo spelaea (Goldfuss, 1810) skeleton (skeleton 3 ) from the Srbsko Chlum-Komín Cave of the Bohemian Karst (Czech Republic). • A - second right costa (NMP No. Ra 4225). • B - third right costa (NMP No. Ra 4226). - C - fourth right costa (NMP No. Ra 4227). $\bullet$ D - fifth right costa (NMP No. Ra 4228). $\bullet$ E - sixth right costa (NMP No. Ra 4248). $\bullet$ F ninth right costa (NMP No. Ra 4233). • G - tenth right costa (NMP No. Ra 4234). • H - eleventh right costa (NMP No. Ra 4235). • I - twelfth right costa (NMP No. Ra 4236). $\bullet \mathrm{J}$ - thirteenth and last right costa (NMP No. Ra 4237). $\bullet \mathrm{K}$ - first left costa (NMP No. R 4238). $\bullet$ - second left costa (NMP No. Ra 4239). $\bullet \mathrm{M}$ - sixth left costa (NMP No. Ra 4243). $\bullet \mathrm{N}$ - seventh left costa (NMP No. Ra 4244). $\bullet \mathrm{O}$ - ninth left costa (NMP No. Ra 4246). $\bullet$ P - tenth left costa (NMP No. Ra 4247). $\bullet$ Q - thirteenth and last left costa (NMP No. Ra 4251). $\bullet$ R -first sternal bone (NMP No. Ra 4252). S - middle sternal bone (NMP No. Ra 4253). All in inner lateral view.

include fragments of the processes. Some vertebrae still have parts missing as a result of damage that occurred during excavation. The cervical column (Fig. 7A-G) is complete, with all seven vertebrae present, but most of these show recent damage on their processes. The thoracic vertebral column (Fig. 7H-R) is incomplete, as only 12 vertebrae are present; there should be 13 in the Felidae. One vertebra from the middle thoracic region is missing and another is only represented by the dorsal spine. The lumbar vertebral column (Fig. 7S-V), which in the felids consists of seven vertebrae, is missing three large vertebra centra, of which most of the processes seems to be present. Even the half lumbar vertebra 7 is present. Fifteen caudal vertebrae (Fig. 7W-JJ) are present from the tail, including the last two fused vertebrae from the tip. Since a complete tail in the Felidae has about 22 vertebrae, some are clearly missing.

The thorax includes one of the best preserved and most complete rib cages known (Fig. 8A-Q). Some ribs are missing the rib heads, but their distal ends have at least been preserved. $P$. $l$. spelaea has 13 ribs on each side correlating to the 13 thoracic vertebrae. All 26 ribs are represented in this lioness skeleton, and are more or less complete. The right rib

Figure 9. Appendicular skeleton of the young adult lioness Panthera leo spelaea (Goldfuss, 1810) skeleton from the Srbsko Chlum-Komín Cave of the Bohemian Karst (Czech Republic). • A - right scapula (NMP No. R 4415), lateral. • B - left scapula (NMP No. Ra 4233), lateral. • C - right humerus (NMP No. R 4417), cranial. • D - left humerus (NMP No. R 4522), cranial. • E - right ulna (NMP No. R 4418), cranial. • F - left ulna (NMP No. R 4419), cranial. $\bullet \mathrm{G}$ - right radius (NMP No. R 4420), cranial. $\bullet \mathrm{H}-$ left radius (NMP No. R 4421), cranial. $\bullet$ I - right pisiform (NMP No. R 4621 ), dorsal. $\bullet$ J - left pisiform (NMP No. R 4934), cranial. $\bullet \mathrm{K}$ - left scapholunatum (NMP No. R 4606), cranial. $\bullet$ L - pelvis, a - dorsal, b - lateral left. • M - right femur 


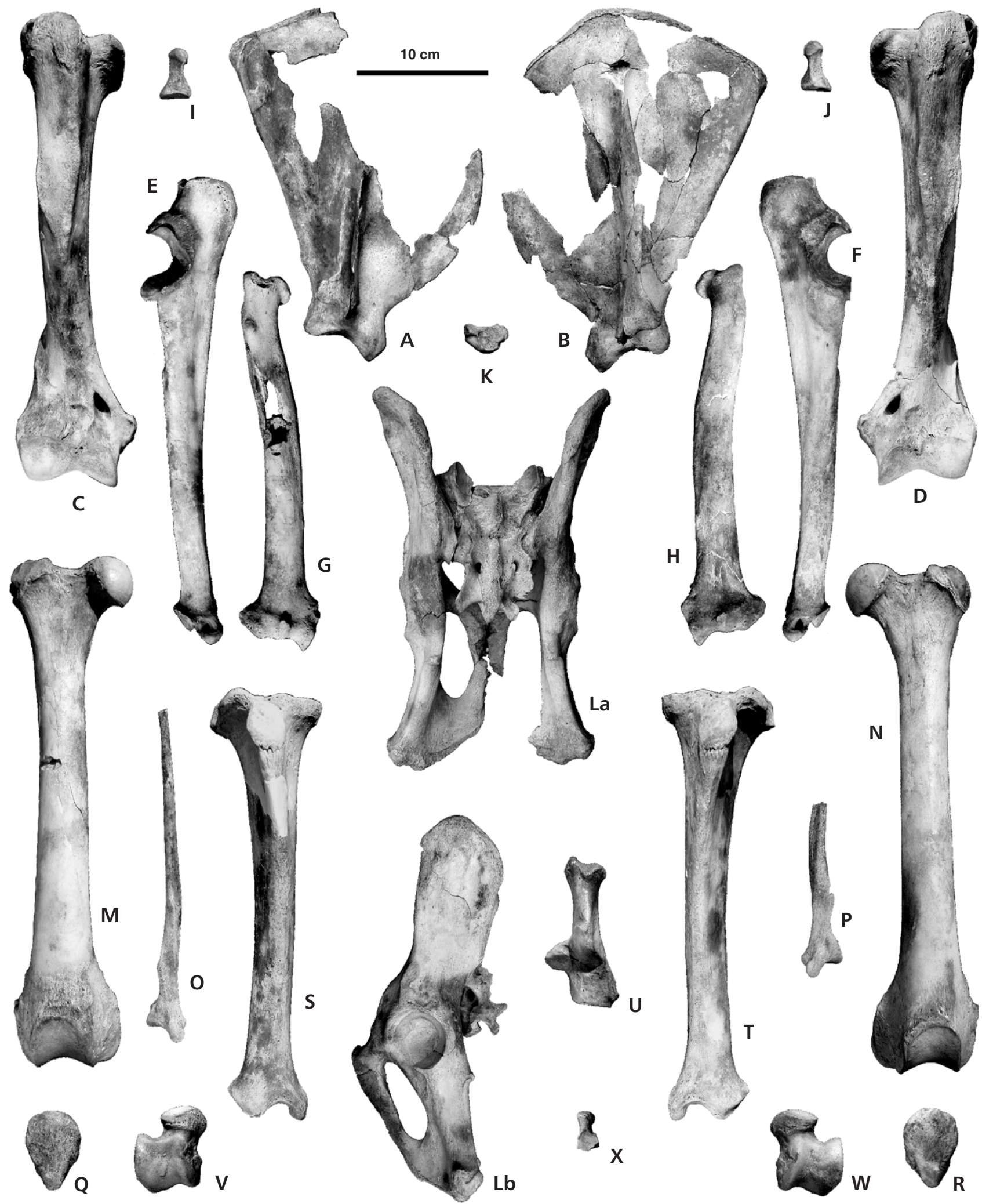

(NMP No. R 4525), cranial. $・ \mathrm{~N}$ - left femur (NMP No. R 4526), cranial. • O - incomplete right fibula (NMP No. R 4607), lateral. $\bullet$ P - incomplete left fibula (NMP No. R 4532), lateral. • Q - right patella (NMP No. R 4602), cranial. • R - left patella (NMP No. R 4533), cranial. • S - right tibia (NMP No. R 4528), cranial. • T - left tibia (NMP No. R 4527), cranial. • U - left calcaneus (NMP No. R 4530), cranial. • V - right astragal (NMP No. R 4914), dorsal. • W - left astragal (NMP No. R 4531), dorsal. • X - left tarsal II (NMP No. Ra 4232), cranial. 
Table 2. Important measurements of the Panthera leo spelaea skeleton from Srbsko Chlum-Komín of the Bohemian Karst (Czech Republic) for the sex identification (in $\mathrm{cm}$ ). The measurements show low proportions and indicate well a female individual (all in $\mathrm{mm}$ ).

\begin{tabular}{|c|c|c|c|c|c|c|}
\hline 1 & R 4406 & Cranium & Total length: 305 & 165 & Width P4: 34 & Width C: 21 \\
\hline 2 & R 4407 & Lower jaw & Total length: 214 & Height behind M1: 48 & Width M1: 28 & Width C: 21 \\
\hline 3 & R 4522 & Humerus (left) & Total length: 319 & Smallest width middle of shaft: 29 & Proximal width: 75 & Distal width: 84 \\
\hline 4 & R 4419 & Ulna (left) & Total length: 342 & Width under proximal joint: 48 & Proximal width: 60 & Distal width: 34 \\
\hline 5 & R 4421 & Radius (left) & Total length: 288 & Smallest width middle of the shaft: 29 & Proximal width: 39 & Distal width: 62 \\
\hline 6 & R 4523 & Pelvic & Total length: 312 & Width "canal": 92 & Acetabular width: 132 & $\begin{array}{l}\text { Sacrum length: } 102 \\
\text { Acetabulum length: } 42 \\
\text { Length foramen obturatum: } 77\end{array}$ \\
\hline 7 & R 4525 & Femur & Total length: 359 & Smallest width middle of the shaft: 34 & Proximal width: 88 & Distal width: 81 \\
\hline 8 & R 4528 & Tibia & Total length: 312 & Smallest width middle of the shaft: 29 & Proximal width: 84 & Distal width: 59 \\
\hline
\end{tabular}

cage has the following complete ribs: Nos. 2, 5, 6, and 9-13. Of the other ribs, Nos. 1, 3, and 4 have small parts missing, No. 7 has no distal part, and No. 8 has no proximal rib head. In the left rib cage the ribs 1-2, 6, 9 and 13 are complete; all others have some distal parts (Nos. 3-5) or the proximal part (No. 12) missing or, in a few cases, minor damage in the central part of the rib shaft (Nos. 8, 10). The first sternal bone is present as well as one other which could be either the second or third sternal bone (Fig. 8R, S).

The pelvis is almost complete (Fig. 9L) but is still missing a large portion of the posterior part. All bone sutures, except the ones between the pelvic bones and sacrum, are fused, indicating a young adult age.

Appendicular skeleton. - The forelimbs (Fig. 9A-K) are almost fully preserved. Only the distal elements are problematic, i.e. the last phalanges (II-III). The left scapula is almost complete while the right scapula is less complete (Fig. 9A, B). The right humerus has a small fragment missing, while the left one is complete (Fig. 9C, D). The right ulna (Fig. 9E) is complete, as is also the left one (Fig. 9F). Both radii have similar proportions: the left one (Fig. 9H) has a large fragment missing but the right one is complete (Fig. 9G). Both complete pisiform bones are present (Fig. 9I, J). The right scapholunatum is present (Fig. 8K). Half of the metacarpals are missing. All pedal bones have been sorted from the nearly complete manus and pes metapodial sets of the juvenile animal, which are again smaller and contain all $\mathrm{Mc}$ II-V of the right and left manus. Only the right Mc III-V and the left Mc I, IV-V seem to be present from the adult female skeleton. At least one phalanx I was separated from the juvenile material. Only three phalanges from the right manus and three from the left manus can probably be attributed to the lioness skeleton. The origin of phalanx II was much more difficult to distinguish and it is even difficult to determine a right or left position. The exact positions of the phalanx II, and also the phalanx III, have therefore not yet been identified. They may even belong to the pedal skeletons, or have derived from the cub skeleton.
Both hind limb bones (Fig. 9M-X) are almost complete. Both femora, the patellae and the tibiae are only partly complete (Fig. 9S, T). Only half of the fibulae are present. The left calcaneus (Fig. 9U) is present but the right one is absent. Both astragals (Fig. 9V, W) are preserved and are larger then those from the juvenile animal. Two left tarsals (cuboid, navicular) are complete, whereas only half of the tarsal II is present (Fig. 9X). The left pes includes all large metatarsi II-V. From this left pes two more first phalanges (digit IV, and digit?), one second phalanx (digit II), and possibly all third phalanges are present. There is again a problem in the attribution of an exact position to this part of the skeleton. The phalanges III can be distinguished between the right and the left side as a result of their different angles to the phalanx bases. The exact position of the digits is also uncertain, due at least in part to their being incomplete. Some small phalanx III, which have been attributed to the outer digits, may actually came from to the middle digits of the smaller juvenile animal. The right pedal skeleton has only three complete large metatarsi (V, IV, and II) and half of the proximal metatarsus II. The first phalanx is present from the digits II, III and V. Phalanx II may be represented on digits II-IV, but this is uncertain. Finally, the position of the phalanges III in relation to digits II and V remains unclear.

\section{Discussion}

\section{Sexual dimorphism and individual ages}

The sex of the lions from the Czech Republic can be interpreted through comparisons with other fossils of female and male lions ( $c f$. Turner 1984, Gross 1992, Diedrich 2009b). Females are much smaller then males, as defined differently for cold and warm periods, using osteometrics for the cranium and postcranial bones (Fig. 11) within cold and warm periods, but not between those times. The lioness skeleton from the Eemian site at Neumark-Nord Lake 1 

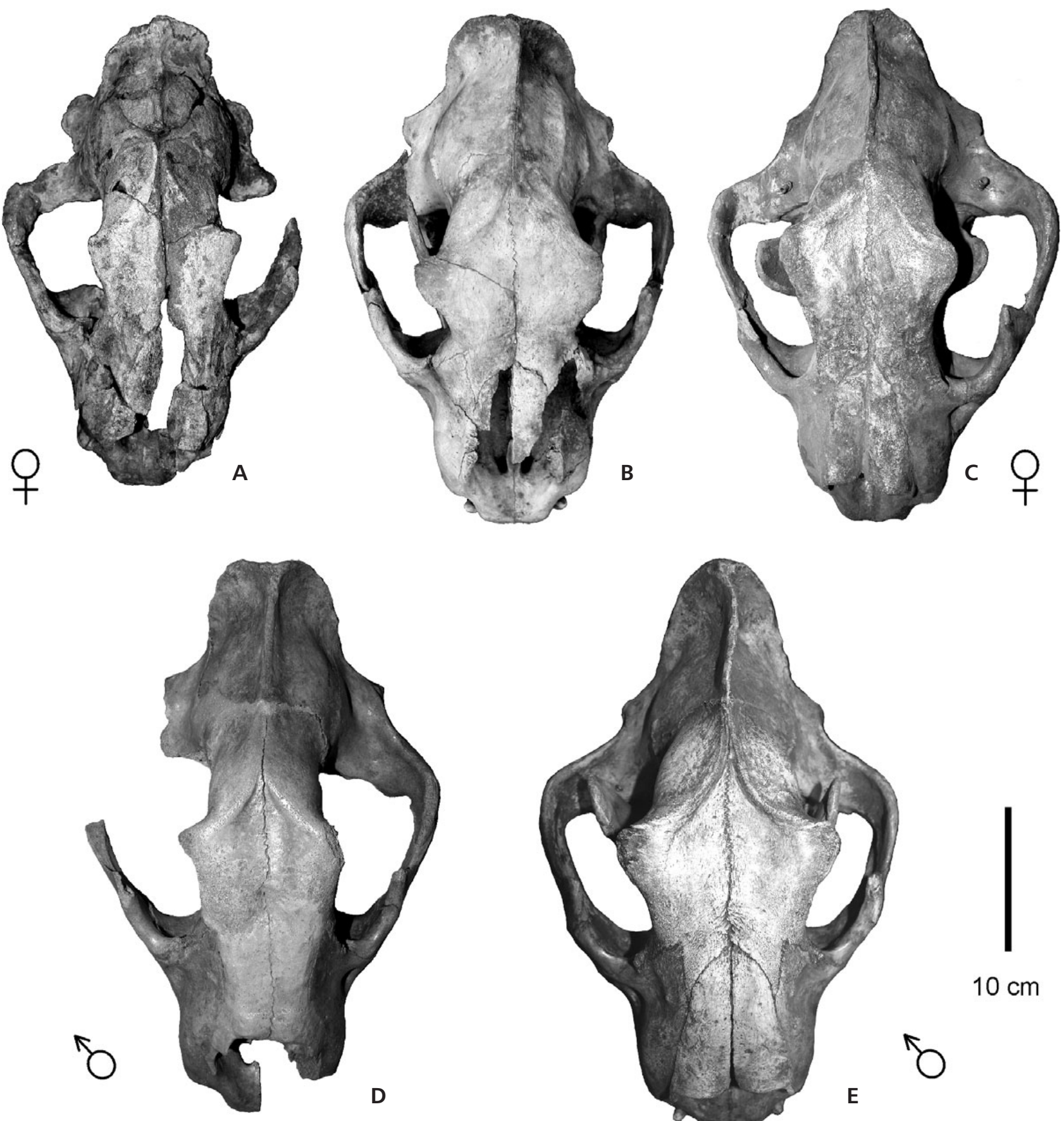

Figure 10. All recently discovered Late Pleistocene steppe lion Panthera leo spelaea (Goldfuss, 1810) crania from the Czech Republic. $\bullet$ A - skull from the open air loess Berounka River terrace Hýskov site near Beroun (MBKB No. 363a). • B - skull with lower jaw from skeleton 3, the young adult lioness skeleton from the Srbsko Chlum-Komín Cave (NHMP No. R 4406). C - skull with lower jaw from the Cut-Stone Gallery of the Sloup Cave composite skeleton 2 (AMB without No.). $・$ D - skull from the Cut-Stone Gallery of the Sloup Cave (AMB No. OK 130570). $・$ E - skull with lower jaw from the Cut-Stone Gallery of the Sloup Cave composite skeleton 1 (NHMV No. 1885/0014/4302). All in dorsal view.

(cf. Diedrich 2010b, c) and a solitary skull from an Italian cave (Bona 2006) were not included in the statistics because steppe lions seem to have been smaller during warm periods (including the present) than in cold periods ( $c f$. Gross 1992), although this is not yet well documented in the fossil record because of the scarcity of Eemian lion material in Europe.

Skeletons 1 and 2 and skull remains from the Sloup Cave. Both skulls of skeletons 1 and 2 from the Sloup Cave fall 
within the range of those from small to medium-sized males (Fig. 11A). The third Late Pleistocene skull from the Sloup Cave, which is the largest of the isolated Czech skulls (Fig. 10D, total length $378 \mathrm{~mm}$, condylus width $72 \mathrm{~mm}$ ), is intermediate in size between skulls 1 and 2. Male skulls from Siegsdorf and Azé are even larger (with lengths between 380 and $420 \mathrm{~mm}, c f$. Gross 1992; Fig. 11), as is the skull of the large male skeleton from Arrikrutz (407 mm, $c f$. Altuna 1981). The long bones of both the Sloup Cave skeletons are dissimilar in length (except the humeri in skeleton 1) but are less mixed in skeleton 1 (Vienna), which consists mainly of male bones ( $c f$. Fig. 11B-F). Skeleton 2 (Brno) is a mixture of male and female remains (Fig. 3B) with significant variations in long bone dimensions ( $c f$. Fig. 11B-F).

Skeleton 3 (Srbsko Chlum-Komin Cave). - The total skull length of this specimen is about $302 \mathrm{~mm}$ which is the same as that of the adult female skull from the Perick Caves in Germany (Fig. 12G; Diedrich 2007b). However, skeleton 3 appears to be from a young animal whose skull proportions are similar to the immature lioness skull from the Urșilor Cave ( $c f$. Fig. 12A, D). A more useful indicator for sex identification is the small upper jaw $\mathrm{P}^{4}$ (Perick Caves: 39 mm; Srbsko Chlum-Komín: 34 mm; Siegsdorf: 40 mm; Arrikrutz: $43 \mathrm{~mm}$ ). Finally, the lower jaws are smaller than those from Siegsdorf and Arrikrutz. The mandible height behind the $\mathrm{M}_{1}$ for the Srbsko Chlum-Komín specimen is only $48 \mathrm{~mm}$, whereas for Siegsdorf it is $55 \mathrm{~mm}$ and for Arrikrutz $60 \mathrm{~mm}$, which which suggests that it is in the female size range. Measurements from skull 3 are clearly inconclusive with regard to the age or sex of this specimen.

Similar variations in dimensions are apparent between the long bones from the Srbsko Chlum-Komín lioness and those from the male lion skeletons of Siegsdorf and Arrikrutz (see Fig. 11). The Srbsko Chlum-Komín specimen is a large female (or young male), while the lion from Siegsdorf is a medium sized male and the lion from Arrikrutz is a very large male.

The lioness from the Srbsko Chlum-Komín Cave is the only immature lion material from that cave and $99 \%$ of the steppe lion material from the Sloup Cave can be attributed to adult animals. A similar situation occurs in almost all of the European cave bear dens in which lion remains have been found, supporting the claim that these caves were not used as "cave lion dens" ( $c f$. Perick Caves, Bilstein Caves: Diedrich 2009a, b, Urșilor Cave: Diedrich et al. 2009).

\section{Lion skull - in-vita damages - lions, hyenas and cave bears as possible bite mark producers}

Three skulls, from the Srbsko Chlum-Komín, Sloup and Zoolithen caves, exhibit damage that occurred while the animal was still alive (Fig. 12A-C). All show damage to the brain-case and saggital crest that was in the process of healing. The observed callus formation and deformation structures were probably a reaction to bite damage. One long tooth scratch mark is clearly visible on the Zoolithen Cave holotype skull (Fig. 12C). The brain-case of the Srbsko Chlum-Komín lion exhibits a trauma on the left side (Fig. 12B) affecting the parietal bone and leaving an elongated depression with a parallel crest. This feature runs parallel to the crista saggitalis over the centre of the parietal bone. This damage also caused a marked deformation of the left side of the brain-case and resulted in complete fusion of the suture between the left parietal and the frontal bones. The parietal fracture or scratch may have affected the entire left side of the brain including motor function, auditory, and sensory areas. The skull from skeleton 1 (Vienna) also seems to have bite damage that caused minor deformation on the parietal. This was almost completely healed by the time of death. Frontal damage to a cave bear skull from the Zoolithen Cave is also partly healed (Fig. 13C). Other brain-case pathologies on a P. l. spelaea cranium from the open air site at Haltern, north-western Germany, that occurred while the animal was still alive, have been described and illustrated previously (Diedrich 2004). This skull shows a large bone growth $1 \mathrm{~cm}$ in diameter on the parietal, close to the saggital crest, which has not yet been explained. Damage and pathologies reported in modern African P. leo (such as partial cerebella hernia Tuch \& Pohlenz 1973), have not been observed in Late Pleistocene steppe lion skulls, and appear different to the bite damage and pathologies on Pleistocene cranial material discussed herein. Other types of depressions in parietals, occurring in the Late Pleistocene sabre tooth cat Smilodon fatalis (e.g., deep pits believed to be neoplasms), have been interpreted to be the result of mechanical strain (Duckler 1997). They are not comparable to the parietal damage presented on the three steppe lion skulls of Fig. 12A-C, which are believed to have had traumatic causes and to most probably result from bite damage caused by canine teeth during fights.

Intraspecific fights between present-day female lions or between male and female lions are quite common and occasionally result in the death of one of the combatants (cf. Palomares \& Caro 1999, Packer \& Pusey 2001). Fights in which lions are critically injured or killed may occur during an attempted takeover of the clan by a male lion or when females vigorously defend their cubs (Estes 1999, Packer \& Pusey 2001). Fighting lions often bite each other in the face and head (Schaller 1972, Packer \& Pusey 2001). Such scenarios could explain the parietal injury and brain damage in the Pleistocene early adult female lion skeleton (Fig. 5) from Srbsko Chlum-Komín and the skulls from the Sloup and Zoolithen caves (Fig. 12A-C), and would also explain the brain-case damage of other Late Pleistocene steppe lions. 

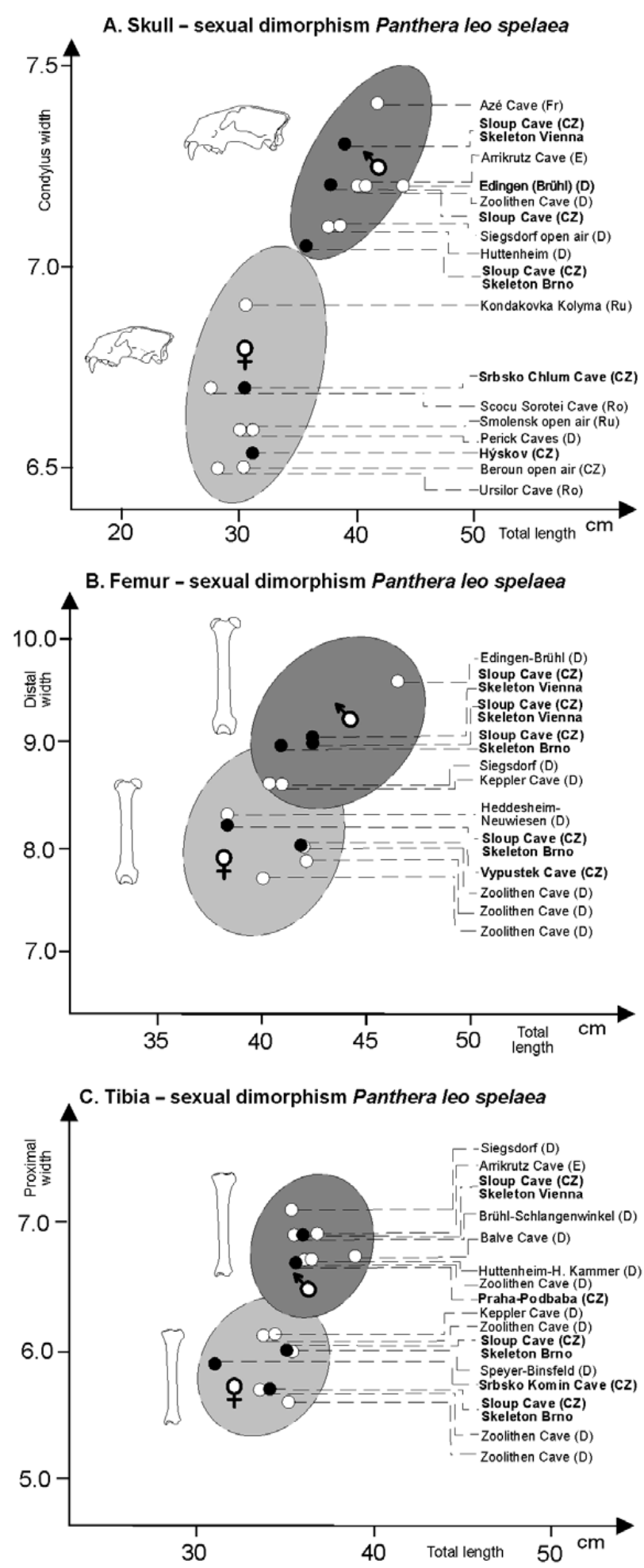

D. Humerus - sexual dimorphism Panthera leo spelaea
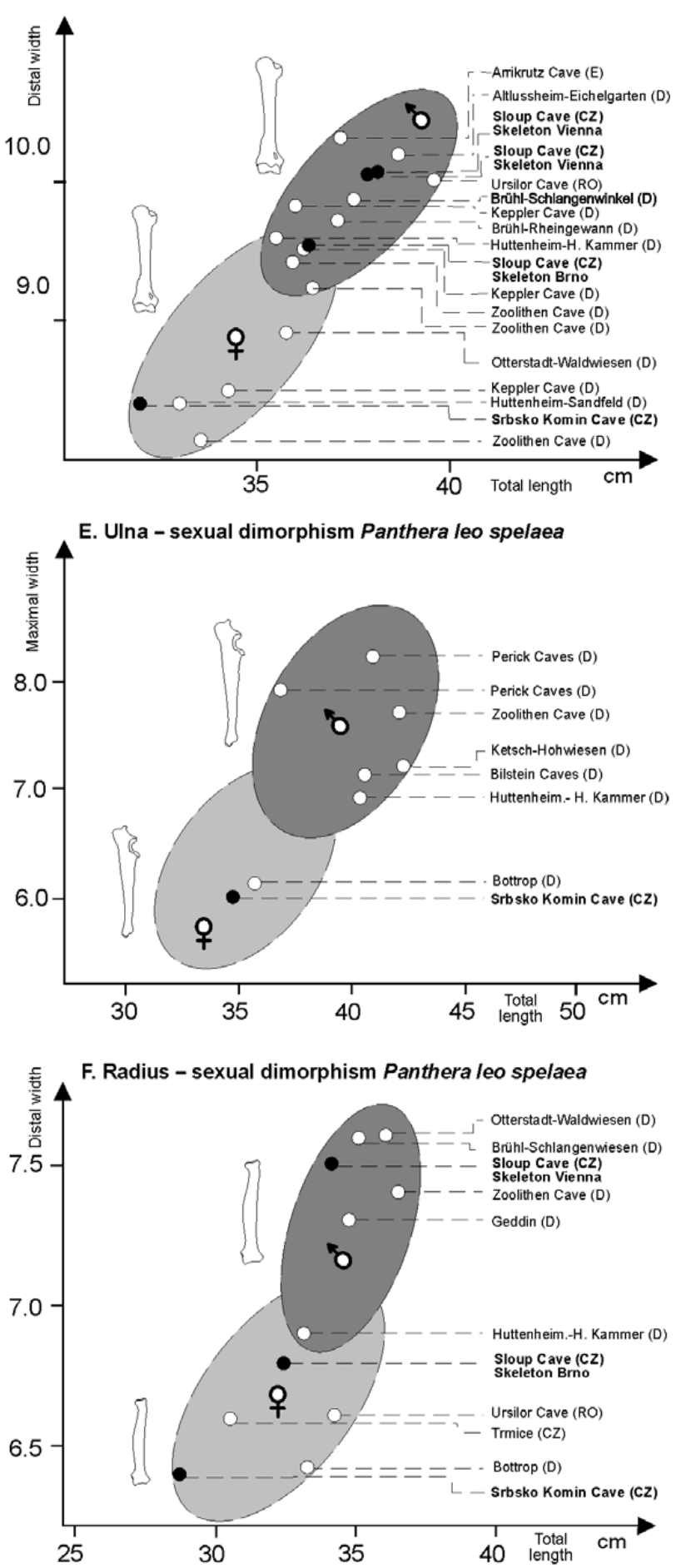

Figure 11. Late Pleistocene Weichselian/Wuermian steppe lion Panthera leo spelaea (Goldfuss, 1810) sexual dimorphism: comparisons of skull and long bone dimensions for Czech Republic material with those from other European sites (composed after Altuna 1981; Argant 1988; Diedrich 2009b, 2011a; Diedrich \& Rathgeber 2011).

Lions are also known to fight for other reasons, including disputes while feeding on a carcass, territorial disputes between prides, and fights between groups of males, which can all result in similar bite wounds (Schaller 1972, Estes 1999, Packer \& Pusey 2001).

Interspecific fights also occur between present-day 


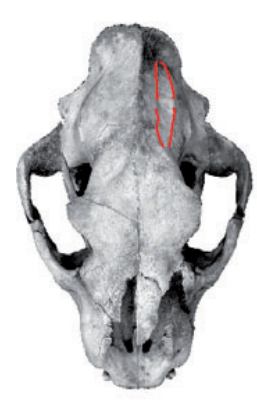

A
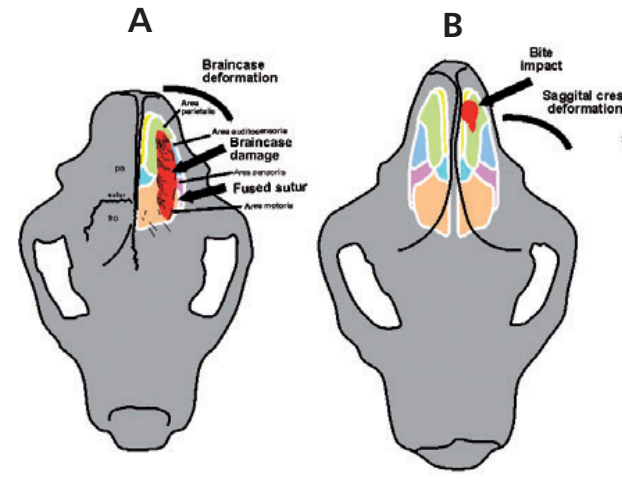

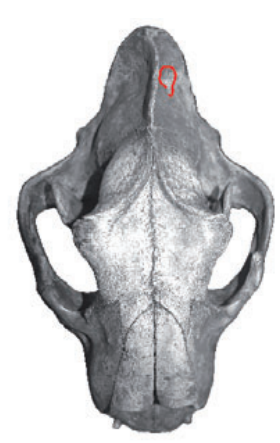

B
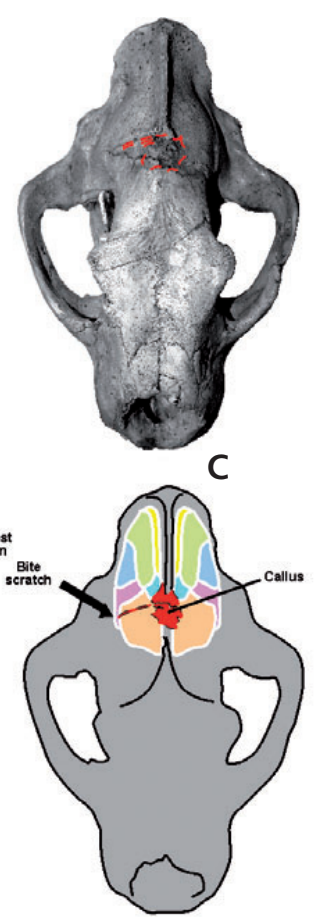
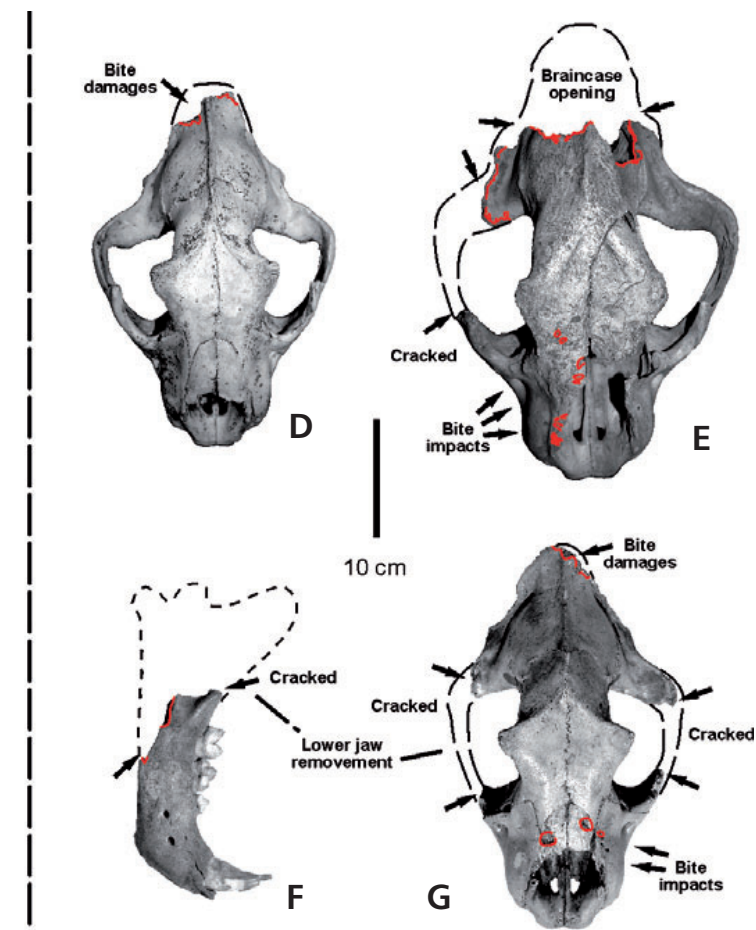

Figure 12. Pre mortem pathologies and post mortem skull damage of the steppe lion Panthera leo spelaea (Goldfuss, 1810). • A - skeleton 3 skull from the Srbsko Chlum-Komín Cave with bite damage on the brain-case, in the process of healing. $\bullet$ B - skeleton 1 skull from the Sloup Cave with bite damage in the process of healing and skull deformation. $\bullet \mathrm{C}$ - holotype skull from the Zoolithen Cave with bite and scratch damage on the saggital crest of the brain-case. $\bullet$ D - scavenged skull from the Urșilor Cave skeleton with bite damage on the occipital. $\bullet$ E - skull from the Zoolithen Cave with brain-case opening and fractured jugal. $\bullet \mathrm{F}-$ lower jaw from the Perick Caves, fractured to remove it from the skull. $\bullet \mathrm{G}-$ skull from the Perick Caves with jugal arches fractured for lower jaw removal.

lions and hyenas, with C. c. crocuta being one of the main predators in Africa. There are several animal species that can kill hyenas, but lions are their main killers ( $c f$. Joubert \& Joubert 2003). In one study 13 out of 24 hyena carcasses found had been killed by lions (Kruuk 1972, Joubert \& Joubert 2003) and a similar situation is likely to have existed with the Late Pleistocene lions and Ice Age spotted hyenas. Possible supporting evidence comes from hyena skull from the Zoolithen Cave (Fig. 13A) which exhibits considerable bite damage that had partly healed, although it can not yet be accurately determined from the fossil record whether specific injuries were conspecific or inflicted by another species. Similarly for attacks on the steppe lion skull from the same cave (Fig. 13B). Actualistic comparisons will need to be made in future on present day hyenas and lions to compare the different types of damage inflicted by their bites. Where lions are separated from their pride or are not integrated into a pride, individual African lions do feed on carcasses in order to survive in emergencies (Estes 1999). If the injured young lioness from the Srbsko Chlum-Komín Cave tried to intrude into a hyena den, the chances of it winning a battle with hyenas defending their prey-storage and cub-raising den site would be extremely low. Such a defence of dens and juveniles provides the reason for most of the lion kills by present-day hyenas in Af- rica (Estes 1999, Packer \& Pusey 2001). In contrast, African spotted hyenas are well known to kill lion cubs, juveniles, and weak or sick adult lions (Schaller 1972, Estes 1999). Consumption of the victim appears to be more common when food is scarce or a matter of dispute (Palomares \& Caro 1999), which explains the presence of complete Pleistocene lion carcasses in hyena or cave bear den sites.

Interspecific fights between lions and cave bears have no modern equivalent and, possibly as a result, the taphonomy of cave bear den caves in Europe has not been well studied. The theory that steppe lions may have hunted cave bears during the Ice Age was established on the basis of new discoveries at the Urșilor Cave and other sites in Germany and the Czech Republic (cf. Diedrich 2009b, 2010e, 2011f). A first study of the cave bear bone taphonomy in the Zoolithen Cave (Diedrich 2011f) has suggested new explanations for partly healed bite marks on the brain-cases (frontals) of cave bears ( $c f$. Fig. 13C). Only in the Zoolithen Cave have such impressively damaged skulls of the two large cave inhabitants (hyenas and cave bears) and other cave dwellers (lions) been found, prompting the theory that hyenas scavenged on cave bears and that the cave bears were actually hunted by lions (Diedrich 2010e, 2011f). The cranial damage inflicted on living cave 


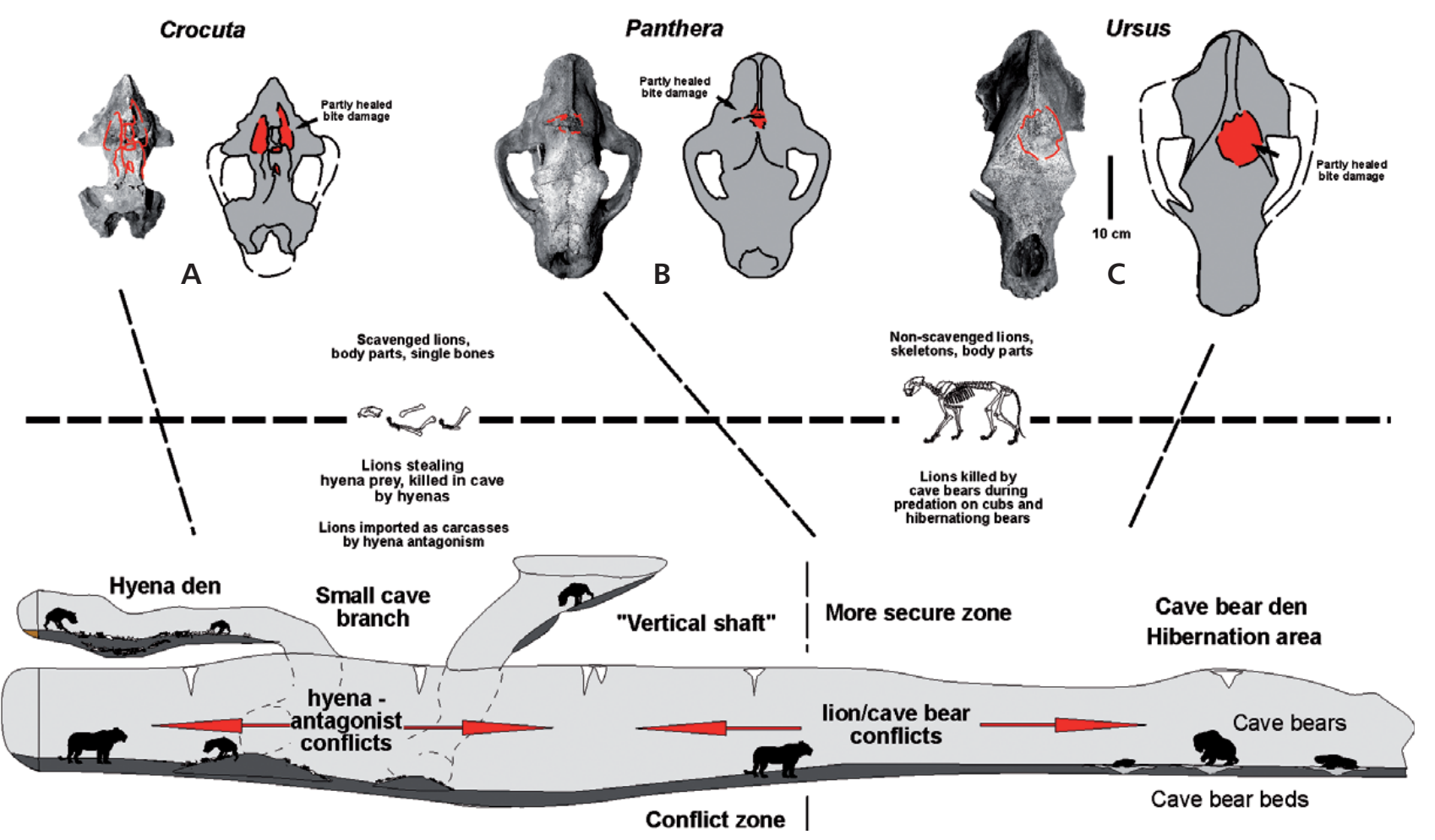

Figure 13. Cave model for the Sloup Cave, Zoolithen Cave, and other large European caves that were used as hyena and cave bear dens. $\bullet$ A-C - three skulls from the Zoolithen Cave all have partly healed bite damage on the brain-case (material in the MB and UE). Such damage could have resulted from different scenarios such as conflicts between hyenas or lions and their cave bear prey, or from interspecies fights, either inside or outside the cave. Lion skeletons from cave bear dens, such as those from the Sloup Cave, are all found deep within the caves whereas incomplete and gnawed lion bones in the hyena den area appear in several cases to have been imported lion remains.

bears could also be possibly attributable to intraspecific aggression. It is further postulated that battles between cave bears and lions may have occurred deep within the cave, in areas that would have been inaccessible to hyenas due to their relatively poor climbing skills (e.g. Urșilor Cave, Diedrich 2011f). Cave bears may thus have deliberately sought deep caves in which to hibernate, as protection against lion predation (Diedrich 2009b, 2011f).

\section{Lion skull - post mortem damage and hyena scavenging}

Some of the bite damage on lion skulls is obviously post mortem damage, including that seen on the three skulls from the Urșilor, Zoolithen and Perick caves (Fig. 12D-G). The bite marks show no sign of healing and are typically round or oval to triangular, many with associated scratch marks. In some instances portions of the bones have been chewed off. In the Zoolithen Cave skull, the brain-case must have been opened from the occipital side by a large carnivore as a missing jugal arch has also been chewed. Jugal arch damage is also demonstrated on both sides of the skull from the Perick Caves (Fig. 12G). The lower jaw from this skull has also been fractured diagonally behind the last molar tooth in order to facilitate its removal from the skull (Fig. 12F). The predation of Ice Age spotted hyena on lions and importation of their carcases into hyena cave dens may provide an explanation for the general male/female ratios in late Pleistocene bone sites ( $c f$. Diedrich 2009a). Modern spotted hyenas do not usually hunt adult male lions, although exceptions to this generality have been reported (Kruuk 1972, Estes 1999). Some carcasses of Ice Age steppe lions may have been left outside the caves (or partly imported to hyena dens), as in PrahaPodbaba river terrace open air site and at the Siegsdorf open air river terrace and lake site in Germany, although the importation of male lion carcasses has now been demonstrated in some European hyena dens ( $c f$. Diedrich $2007 \mathrm{c}, 2009 \mathrm{a}$ ). There is a correlation between the more damaged lion bones and their occurrence at hyena den sites and prey-bone accumulations. Where there were no hyenas occupying the entrances or side-branches of cave bear den cave systems ( $c f$. Fig. 13) the damage to skeletons is reduced, as has recently been shown for the Urșilor Cave (Diedrich 2011f). In the Zoolithen Cave, the large hyena population was also thought to have been responsible for the high proportion and degree of damaged cave bear bones, as has also been described for the Perick Caves and other cave bear den sites in Europe ( $c f$. Diedrich 2011f). The bite 
damage left by hyenas on cave bear bones is similar to that illustrated herein on lion remains. The lion skulls from the Perick Caves (Fig. 12F, G) - as well as remains from the Sloup Cave ( $c f$. Diedrich 2011b) - that have possibly been chewed and cracked by hyenas exhibit typical damage to the jugal arches caused during removal of the lower jaw, which also resulted in cracking of the mandibles. While hyenas seem to have been the main scavengers on lion carcasses it remains a possibility that, in stressful situations, lions that perhaps became trapped in a complex cave system with several different levels might have engaged in cannibalism (e.g. Urșilor Cave: Diedrich 2011f).

\section{Conclusions}

The historical skeleton finds from the Cut-Stone Gallery in the Sloup Cave of the Moravian Karst (Czech Republic) are both composite skeletons. Skeleton 1 (Vienna) includes a higher proportion of original bones, which have come from a single male skeleton. Both of these composite skeletons include about $30 \%$ to $50 \%$ bone casts and also pedal bones from the Výpustek Cave in the Czech Republic. The lion bones and skeletal remains were found either within hyena dens and prey-bone accumulations, or deeper within cave bear dens. The material from the Sloup Cave indicates derivation from several different steppe lion Panthera leo spelaea (Goldfuss, 1810) skeletons, found within the cave bear hibernation areas deep inside the cave, with all of the material being from adult lions or lionesses. This situation is different from the relatively complete original skeleton of a diseased, young adult lioness from the Srbsko Chlum-Komín Cave hyena den site in the Bohemian Karst (Czech Republic), which may have been killed by the hyena clan that occupied the same cave, when it attempted to steal their prey. In overlapping hyena and cave bear dens such as the Sloup Cave and the German Zoolithen Cave, the lion bone taphonomy is more complex. Hyenas appear to have dispersed the lion skeletons and may also have imported parts of some lion carcasses for consumption inside the cave. In so doing, they damaged bones, opened brain-cases in order to feed on the brain, and fractured the lower jaws. Injuries on steppe lion skulls from different caves, that were in the process of healing, provide evidence of either intraspecific conflicts between lions or interspecific fights between lions and either hyenas or cave bears (e.g., partly healed cranial bite damage, Zoolithen Cave (Fig. 12). The presence of articulated lion skeletons deep inside cave bear dens can be explained by interspecific fights during predation by lions on cave bears, in which lions were killed by bears. Less then $1 \%$ of the bones in cave bear dens are from steppe lions but it appears that, from time to time, a lion intent on predation may have been killed by the cave bears protecting their cubs. Cave bears were not carnivorous and hence would not have fed on any lions that they killed, and hyenas often had no access to the deeper passages in the caves. The presence of steppe lion skeletons such as the three recently discovered between articulated cave bear skeletons and bonebeds on hibernation plateaus deep within the Romanian Urșilor Cave, appear to offer a taphonomic model for the presence of steppe lion carcasses and bones in other large cave bear dens such as the Sloup Cave, the Výpustek Cave, the Zoolithen Cave, the Perick Caves, and many other European sites.

\section{Acknowledgements}

The collection in the Natural History Museum, Vienna, was studied with the support of U. Göhlich, and the collection in the National Museum, Prague with the support of K. Zágoršek. A visit to inspect the collections in the Anthropos Museum, Brno, was possibly with permit from M. Oliva. R. Musil (University of Brno) acted as guide in the Sloup and Výpustek caves and also provided access to relevant literature. O. Hampe (Museum of Natural History of the Humboldt University Berlin) and B. Hilpert (University of Erlangen) allowed the study of Zoolithen Cave material. The FHKF speleological club assisted with the cave fieldwork and with new exploration and research in the spring and summer of 2010. The first draft was kindly reviewed and corrected by R. Musil and P.A. White. The final spell-check and comments were thankfully made by E. Manning.

\section{References}

Altuna, J. 1981. Fund eines Skelettes des Höhlenlöwen (Panthera leo spelaea Goldfuss) in Arrikrutz, Baskenland. Bonner zoologische Beiträge 32(1-2), 31-46.

Argant, A. 1988. Étude de l'exemplaire de Panthera spelaea (Goldfuss, 1810) (Mammalia, Carnivora, Felidae) du gisement Pleistocène moyen recent de la grotte d'Aze (Saone et Loire). Revue de Paléobiologie 7(2), 449-466.

BonA, F. 2006. Systematic position of a complete lion-like cat skull from the Eemian ossiferous rubble near Zandobbio (Bergamo, North Italy). Rivista Italiana di Paleontologia e Stratigrafia 112(1), 157-166.

Burger, J., Rosendahl, W., Loreille, O., Hemmer, H., Eriksson, T., GötherströM, A., Hiller, J., Collins, M.J., Wess, M.J.T. \& Alt, K.W. 2004. Molecular phylogeny of the extinct cave lion Panthera leo spelaea. Molecular Phylogeny and Evolution 30, 841-849. DOI 10.1016/j.ympev.2003.07.020

DiedRICH, C. 2007a. Upper Pleistocene Panthera leo spelaea (Goldfuss, 1810) skeleton remains from Praha-Podbaba and other lion finds from loess and river terrace sites in Central Bohemia (Czech Republic). Bulletin of Geosciences 82(2), 99-117. DOI 10.3140/bull.geosci.2007.02.99

Diedrich, C. 2007b. The fairy tale about the "cave lions" Panthera leo spelaea (Goldfuss 1810) of Europe - Late Ice Age spotted hyenas and Ice Age steppe lions in conflicts - lion killers and scavengers around Prague (Central Bohemia). 
Scripta Facultatis Scientiarum Universitatis Masarykianae Geology 35(2005), 107-112.

Diedrich, C. 2008. The holotypes of the Upper Pleistocene Crocuta crocuta spelaea (Goldfuss, 1823: Hyaenidae) and Panthera leo spelaea (Goldfuss, 1810: Felidae) of the Zoolithen Cave hyena den (South Germany) and their palaeo-ecological interpretations. Zoological Journal of the Linnaean Society London 154, 822-831.

Diedrich, C. 2009a. Steppe lion remains imported by Ice Age spotted hyenas into the Late Pleistocene Perick Caves hyena den in Northern Germany. Quaternary Research 71(3), 361-374. DOI 10.1016/j.yqres.2008.12.006

Diedrich, C. 2009b. Upper Pleistocene Panthera leo spelaea (Goldfuss, 1810) remains from the Bilstein Caves (Sauerland Karst) and contribution to the steppe lion taphonomy, palaeobiology and sexual dimorphism. Annales de Paléontologie 95(2009), 117-138. DOI 10.1016/j.annpal.2009.07.001

Diedrich, C. 2009c. A Late Pleistocene wolverine Gulo gulo (Linné, 1758) skeleton remain from the Sloup Cave in the Moravian Karst, Czech Republic. Annalen des Naturhistorischen Museums Wien 110A, 123-132.

DiEDRICH, C. 2010a. Specialized horse killers in Europe - foetal horse remains in the Late Pleistocene Srbsko Chlum-Komín Cave hyena den in the Bohemian Karst (Czech Republic) and actualistic comparisons to modern African spotted hyenas as zebra hunters. Quaternary International 220(1-2), 174-187. DOI 10.1016/j.quaint.2010.01.023

Diedrich, C. 2010b. Ein Skelett einer kranken Löwin Panthera leo spelaea (Goldfuss 1810) und andere männliche Löwenreste aus Neumark-Nord. Archäologie in Sachsen-Anhalt Sonderband, 432-441.

Diedrich, C. 2010c. A diseased Panthera leo spelaea (Goldfuss 1810) lioness from a forest elephant graveyard in the Late Pleistocene (Eemian) interglacial lake at Neumark-Nord, central Germany. Historical Biology 2010(4), 1-23. DOI 10.1080/08912963.2010.507814

Diedrich, C. 2010d. The Late Pleistocene steppe lion Panthera leo spelaea (Goldfuss 1810) population from the Zoolithen Cave (Bavaria) Germany - cave bear predation adaptation in middle mountainous taiga forest environments of Central Europe. Abstract, $16^{\text {th }}$ international cave bear symposium Azé, France.

DiEDRICH, C. 2010e. The holotype skull of "Ursus spelaeus Rosenmüller 1794" - insight to the cave bear bone taphonomy in the Zoolithen Cave (Bavaria) Germany - and contribution to the exploration history, cave genesis, and sedimentology. Abstract, $16^{\text {th }}$ international cave bear symposium Azé, France.

Diedrich, C. 2011a. The largest steppe lion Panthera leo spelaea (Goldfuss 1810) population from the Zoolithen Cave (Bavaria) Germany: specialised cave bear predators of Europe. Historical Biology 23(2-3), 271-311.

DOI 10.1080/08912963.2010.546529

Diedrich, C. 2011b. The Ice Age spotted Crocuta crocuta spelaea (Goldfuss 1823) population, their excrements and prey from the Late Pleistocene hyena den Sloup Cave in the Moravian Karst, Czech Republic. Historical Biology (in press). DOI 10.1080/08912963.2011.591491

Diedrich, C. 2011c. A Late Pleistocene lion Panthera leo spelaea (Goldfuss 1810) skull and other postcranial remains from the
Sloup Cave in the Moravian Karst, Czech Republic. Acta Archaeologica 2011, 19-28.

Diedrich, C. 2011d. Late Pleistocene steppe lion Panthera leo spelaea (Goldfuss, 1810) footprints and bone remains from open air sites in northern Germany - Evidence of hyena-lion antagonism and scavenging in Europe. Quaternary Science Reviews 30(15-16), 1883-1906.

DOI 10.1016/j.quascirev.2011.03.006

DiedRICH, C. 2011e. Pleistocene Panthera leo spelaea (Goldfuss 1810) remains from the Balve Cave (NW Germany) - a cave bear, hyena den and Middle Palaeolithic human cave, and review of the Sauerland Karst lion sites. Quaternaire 22(2), $105-127$.

DiedRICH, C. 2011f. Cave bear killers and scavengers in the Final Ice Age of Europe - feeding specialization as reaction on the mammoth steppe fauna absence in mountainous regions. Quaternary International (in press).

Diedrich, C. \& RATHgeber, T. 2011. Late Pleistocene steppe lion Panthera leo spelaea (Goldfuss 1810) skeleton remains of the Upper Rhine valley (SW Germany) and contribution to their sexual dimorphism, taphonomy and habitus. Historical Biology (in press). DOI 10.1080/08912963.2010.549943

Diedrich, C., Robu, M., Dragusin, V., Constantin, S. \& MolDOVAN, O. 2009. New Upper Pleistocene steppe lion skeleton finds between the cave bear hibernation plateaus of the Ursilor Cave bear den, Romania. Abstract, $15^{\text {th }}$ International Cave Bear Symposium, Spišská Nová Ves, Slovakia.

DiedRICH, C. \& Ž́́́, K. 2006. Upper Pleistocene hyena Crocuta crocuta spelaea (Goldfuss, 1823) prey deposit and den sites in horizontal and vertical caves of the Bohemian Karst (Czech Republic). Bulletin of Geosciences 81(4), 237-276.

DuCKLER, G. 1997. Parietal depressions in skulls of the extinct saber-toothed felid Smilodon fatalis: evidence of mechanical strain. Journal of Vertebrate Paleontology 17(3), 600-609.

Estes, R. 1999. The Safari Companion: A Guide to Watching African Mammals. Chelsea Green Publishing Company, Vermont.

Gross, C. 1992. Das Skelett des Höhlenlöwen (Panthera leo spelaea Goldfuss 1810) aus Siegsdorf/Ldkr. Traunstein im Vergleich mit anderen Funden aus Deutschland und den Niederlanden. Unpublished Dissertation, Tierärztliche Fakultät der Maximilians-Universität, München.

GoldFuss, G.A. 1810. Die Umgebungen von Muggendorf. Ein Taschenbuch für Freunde der Natur und Altertumskunde. Erlangen.

Joubert, D. \& Joubert, B. 2003. Eternal Enemies: Lions and Hyenas. Wildlife Films Botswana for National Geographic, DVD.

KAFKA, J. 1903. Fossile und Recente Raubthiere Böhmens (Carnivora). Archiv der Naturwissenschaftlichen Landesdurchforschung von Böhmem 10(6), 1-120.

KRUUK, H. 1972. The spotted hyena. A story of predation and social behavior. University of Chicago Press, Chicago.

Musil, R. 1956. Mährische Fundstellen Pleistozäner Wirbeltiere. Geologie 5, 159-179.

Musil, R. 2002. Sloupsko-šošůvské jeskyně. 178 pp. Publishing house Gloria, Brno.

PACKer, C. \& Pusey, A. 2001. Egalitarianism in Female African Lions. Science 293(5530), 690-693.

DOI 10.1126/science.1062320 
Palomares, F. \& Caro, T.M. 1999. Interspecific killing among mammalian carnivores. The American Naturalist 153, 492-508.

SCHALLER, G. 1972. The Serengeti Lion. A Study of Predator-Prey Relations. University of Chicago Press, Chicago.

Seitl, L. 1998. Paleontologické výzkumy ve Sloupských jeskyních (severní část Moravského krasu). Acta Musei Moraviae, Scientiae geologicae 83, 123-145.

Smuts, G.L., Anderson, J.L. \& Austin, J.L. 1978. Age determination of the African lion (Panthera leo). Journal of Zoology $185,115-148$.

Tichy, G. 1985. Über der Fund eines Höhlenlöwen (Panthera felis spelaea Goldfuss) aus dem Tennengebirge bei Salzburg. Mitteilungen der Gesellschaft für Salzburger Landeskunde 125, 845-864.

Tuch, K. \& Pohlenz, J. 1973. Partial cerebellar hernia in the lion (Panthera leo L.). Pathological findings in the cerebellum and skull. Veterinary Pathology 10(4), 299-306.

Turner, A. 1984. Dental sex dimorphism in European lions (Panthera leo L.) of the Upper Pleistocene: Palaeoecological and palaeoethological implications. Annales Zoologici Fennici 21, 1-8.

Wankel, J. 1858. Über den Fund- und Lagerstätten fossiler Knochenreste vorweltlicher Thiere, insbesondere jener in der Slouper-Höhle in Mähren. Mitteilungen der kaiserlichköniglichen mährisch-schlesischen Gesellschaft für Ackerbau und Landeskunde 23, 186-188.

Wankel, J. 1868. Die Slouper Höhle und ihre Vorzeit. Denkschriften der kaiserlichen Akademie der Wissenschaften, mathemathisch naturwissenschaftliche Klasse 28, 95-131.

Wankel, J. 1888. Obrazy z. Moravského Švýcarska a jeho minulosti. Brno.

Wankel, J. 1892. Die prähistorische Jagd in Mähren. Olomouc.

ZAJíčEK, P. 2007. Sloupsko-šošưvské jeskyně. Czech Cave Administration.

ZÁzvorka, V. 1954. Pažní kost lva jeskynního - Panthera (Leo) spealaea, Goldfuss - z „Chlupáčovy sluje“ na Kobyle u Koněprus (Berounsko). C̆asopis Národního muzea 123(2), $168-175$. 